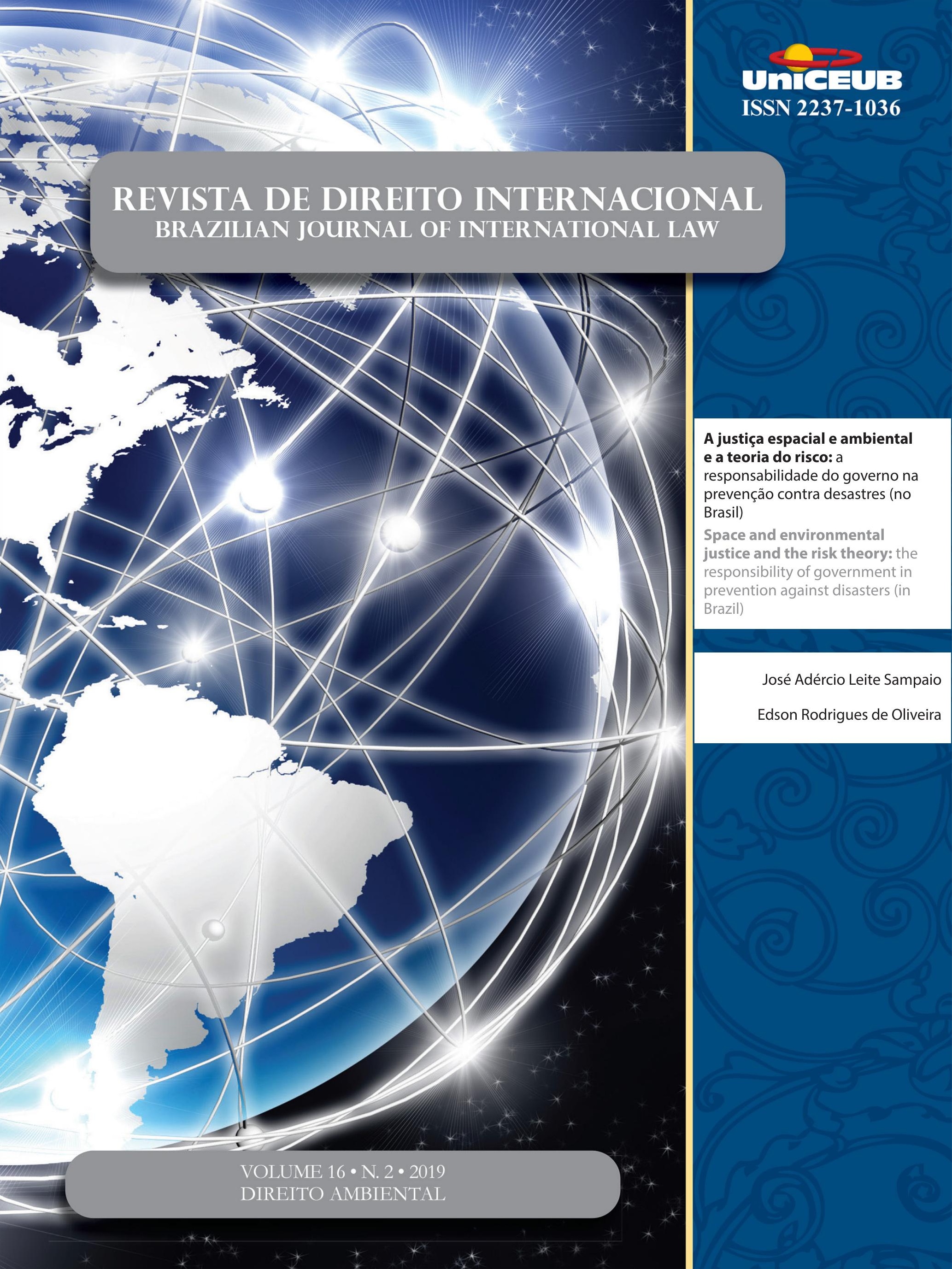




\section{Sumário}

I. Crônicas do Direito Internacional .................................................1

AMAZONIE: LE DROIT INTERNATIONAL EN VIGUEUR APPORTE DES RÉPONSES SUBSTANTIELLES ... 3 Pierre-Marie Dupuy

A eVOluÇão da SOluÇão DE CONTROVÉRSias NOS ACFIs 8 Ana Rachel Freitas da Silva

II. Dossiê Especial: Direito ambientai 14

A brief overview of Sustainable DeVelopment: HOW A DEBATEd CONCEPT With A MUCH-CONTESTED LEGAL NATURE COULD PERFORM A VALUABLE ROLE IN THE DECISION-MAKING ......16 Natali Francine Cinelli Moreira

A meta 11 de Aichi e as Áreas marinhas protegidas em grande ESCALA: proteção ambienTAL OU OPORTUNISMO POLÍTICO?

Alexandre Pereira da Silva

LITIGÂNCIA CLIMÁTICA COMO ESTRATÉGIA JURISDICIONAL AO AQUECIMENTO GLOBAL ANTROPOGÊNICO E MUDANÇAS CLIMÁTICAS

Délton Winter de Carvalho e Kelly de Souza Barbosa

AsSESSMENT AND CHALlENGES OF CARBON MARKETS

Louise Pigeolet e Arnaud Van Waeyenberge

As abordagens dos países da América Latina e Caribe sobre a mobilidade humana proVOCADA PELAS MUDANÇAS CLIMÁTICAS

Diogo Andreola Serraglio e Heline Sivini Ferreira

Implementation of Legal mechanisms of environmental protection by the South PaCIFIC REGIONAL ORGANIZATIONS 116 Joanna Siekiera 
CONCILIATING THE OVERLAP OF PROTECTED AREAS AND TRADITIONAL TERRITORIES: LEGAL INNOVATIONS FOR BIOLOGICAL DIVERSITY CONSERVATION IN BRAZILIAN PARKS

Nathalia Fernandes Lima e Solange Teles Silva

O USO DE DRONES COMO INSTRUMENTO PARA A CONSERVAÇÃo DA BIODIVERSIDADE NO BRASIL141 Larissa Suassuna Carvalho Barros e Marcia Dieguez Leuzinger

Agrotóxicos e direitos humanos no contexto global: o Brasil EM Risco de Retrocesso?

Marcelo Pretto Mosmann, Letícia Albuquerque e Isabele Bruna Barbieri

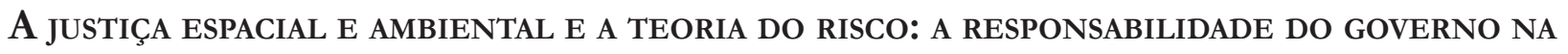
PREVENÇÃo CONTRA DESASTRES (NO BRASIL). 169

José Adércio Leite Sampaio e Edson Rodrigues de Oliveira

The judgment of the case Xucuru People v. Brazil: Inter-American Court of Human RigHTS BETWEEN CONSOLIDATION AND SETBACKS

Gabriela Cristina Braga Navarro

II. Artigos sobre outros temas

NACIONALIDADE: NOVAS REGRAS, VELHOS PROBLEMAS

226

Paulo Henrique Faria Nunes

O EXERCíCIO DA JURISDIÇÃO INTERAMERICANA DE DIREITOS HUMANOS: LEGITIMIDADE, PROBLEMAS E POSSÍVEIS SOLUÇÕES

Felipe Grizotto Ferreira, Guilherme Perez Cabrale Lucas Catib de Laurentiis

A proteção da identidade de gênero na jurisprudênCia da Corte Europeia de Direitos Humanos

Gabriel Coutinho Galil

O COMITÊ JURÍdico INTERAMERICANO dA OEA E A CODIFICAÇÃo DO DIREITO INTERNACIONAL REGIONAL. 
O caso Petruhhin e o princípio do nível mais elevado de proteção no tocante aos diREITOS FUNDAMENTAIS NO ÂMBITO DA UNIÃo EUROPEIA............................................304

Clovis Demarchi e Jaine Cristina Suzin

A AUTONOMia da VONTADE NA ESCOLHA dA LEI APLICÁVEl AOS CONTRATOS DE COMÉRCiO INTER-

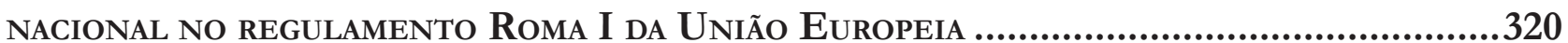

Aline Beltrame de Moura e Rafaela Hörmann

A JuRisdição da ICANN: desafios atuais e Prospectivas futuras...............................335 Aziz Tuffi Saliba e Amael Notini Moreira Bahia

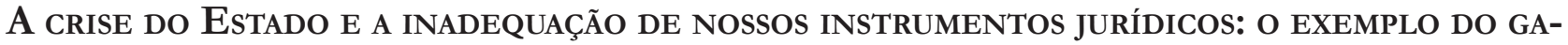
RANTISMO PENAL NO BRASIL.

Oswaldo Poll Costa e Francisco Quintanilha Veras Neto

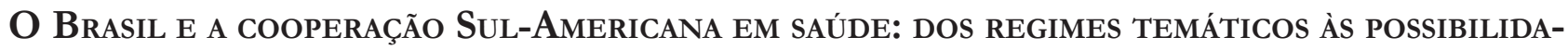
DES DE EFETIVAÇÃo ESTRUTURANTE

Ademar Pozzatti Junior e Luiza Witzel Farias

III. RESENHAS

Resenha da obra: SILVA, Waldimeiry Correa da. Regime internacional de enfrentaMENTO AO TRÁFICO DE PESSOAS: AVANÇOS E DESAFIOS PARA A PROTEÇÃo DOS DIREITOS HUMANOS. Rio de Janeiro: Lumen Juris, 2018. 385

Mércia Cardoso de Souza e Guirino Nhatave 


\title{
A justiça espacial e ambiental e a teoria do risco: a responsabilidade do governo na prevenção contra desastres (no Brasil)*
}

\author{
Space and environmental justice and the risk \\ theory: the responsibility of government in \\ prevention against disasters (in Brazil)
}

\author{
José Adércio Leite Sampaio** \\ Edson Rodrigues de Oliveira***
}

\section{Resumo}

Este artigo estimula reflexões acerca dos riscos de desastres naturais e artificiais e suas consequências hodiernas e vindouras. No tocante às catástrofes, as atividades de segurança pública, que vinculam às atribuições de defesa civil, representam a força física e técnica de resposta do Estado. Os resultados satisfatórios dessas ações congregam múltiplos ramos científicos, mas com respostas interdisciplinares. Historicamente, os desastres eram sinalizados pelo risco vinculado ao quesito da ameaça (potenciais efeitos traumáticos do evento), mas, os iluministas Voltaire e Rousseau, a partir do episódio sísmico de 1755 em Lisboa, fomentaram a migração das atenções para a vulnerabilidade das comunidades frente aos desastres (baixo nível de capacidade de enfrentamento e superação aos efeitos traumáticos do evento). A temática sugere a mister previsibilidade científica das situações de risco de desastres e $\mathrm{o}$ adequado investimento preventivo, antecipando-se ao evento e mitigando perdas e danos. O problema emerge das amostras dos três últimos desastres de barragens de rejeitos de minérios em Minas Gerais, demonstrando objetivamente a adoção do arquétipo arcaico, em detrimento das comunidades e bens vulneráveis. Emprega-se o método hipotético dedutivo, justifica-se a pesquisa pelo crescente potencial de risco de desastres e da vulnerabilidade das pessoas em face das mudanças e dos fenômenos climáticos. No Brasil, há destaque ainda a pluralidade de barragens de rejeitos de mineração em condições análogas às recentemente rompidas.

Palavras-chave: Justiça ambiental. Risco, ameaça e vulnerabilidade. Prevenção aos desastres. Rompimento de barragens.

Membro de corpo editorial da Revista Brasileira de Direito Constitucional (Impresso). E-mail : joseadercio.contato@gmail.com.

*** Bacharel em Direito pela UFMG, Graduado em Segurança Pública pela Academia de Polícia Militar/MG, Graduado em e Gestão Ambiental pela UNOPAR, pós graduado Lato sensu em Teologia, pela FAFH/BH e Segurança Pública pela PUCMinas, Mestre em Direito Ambiental e Doutorando em Direito Ambiental pela Escola Superior Dom Helder Câmara, Belo Horizonte. Oficial do Corpo de Bombeiros Militar de Minas Gerais, no posto de Coronel. E-mail : edsonrol@yahoo.com.br.

\section{Abstract}

This article stimulates reflections on the risks of natural and artificial disasters and their consequences in the present and future days. With regard to disasters, public security activities, which are linked to civil defense tasks, represent the state's physical and technical response strength. The satisfactory results of these actions bring together multiple scientific branches, but with 
interdisciplinary responses. Historically, disasters were signaled by the risk linked to the threat issue (potential traumatic effects of the event), but the Illuminist Voltaire and Rousseau, due to the 1755 seismic episode in Lisbon, fostered the migration of attention to the vulnerability of communities to disaster (low level of coping ability and overcoming the traumatic effects of the event). The theme suggests the scientific predictability of disaster risk situations and appropriate preventive investments, anticipating the event and mitigating losses and damages. The problem emerges from the samples of the last three disasters of mine tailings dams in Minas Gerais, objectively demonstrating the adoption of the archaic archetype, to the detriment of vulnerable communities and goods. The method used is the hypothetical deductive, justifying research on the growing potential for disaster risk and people's vulnerability, especially in the face of climatic changes and phenomena. In Brazil, the plurality of mining tailings dams under similar conditions to those recently ruptured is also highlighted.

Keywords: Environmental justice. Risk, threat and vulnerability. Disaster prevention. Dam rupture.

\section{Introdução}

O presente artigo aborda a origem e a aplicação da visão iluminista sobre a Teoria do Risco de desastre e o surgimento da prevenção como instrumento de mitigação, evoluído até à atualidade. O marco histórico decorreu de 1 de novembro do ano de 1755, em Lisboa - Portugal, com o evento sísmico, seguido de maremoto, com magnitude aproximada de 9 pontos na escala Richter, com estimativas de mais de 10 mil óbitos e devastação patrimonial.

Diante dessa ocorrência, Voltaire e Rousseau propuseram que a racionalidade humana permite a previsão de situações de risco e do planejamento e medidas oportunas de antecipação e mitigação dos efeitos do evento. Nessa senda, a premissa iluminista atribui a culpa dos efeitos prejudiciais do fenômeno ao homem e não à natureza. Esse conceito foi evoluído e operacionalizado, inicialmente, pela França e pelos Estados Unidos, com reverberação gradativa a toda a Europa e a outros países desenvolvidos, nos demais continentes. $\mathrm{Na}$ ocasião dessa tragédia, a configuração conceitual do risco de desastre, que continha o quesito da "ameaça" como cerne (atribuída ao potencial ofensivo do hipotético evento - com ênfase em ações reativas), migrou para a "vulnerabilidade" (das pessoas e do patrimônio, ou seja, a falta capacidade de resposta e proteção destacando as ações preventivas mitigadoras).

Diante dos desastres dos últimos anos, a exemplo dos três últimos rompimentos de barragens de rejeitos de minérios, em Minas Gerais, no Brasil, é perceptível as exacerbadas dissonâncias entre a aplicação desse "conhecimento" em comparação com os respectivos Índices de Desenvolvimento Humanos (IDH) e outros instrumentos de mensuração de vulnerabilidade e risco. O Brasil, na posição 79 (da relação de 189 países), mediante as ações meramente reativas empreendidas, objetivamente, pelos resultados auferidos, por meio de seus órgãos especializados, ao contrário ainda do que determina a Constituição da República Federativa do Brasil (CRFB), não tem demonstrado interesse na aplicação de ações preventivas (mas apenas reativas). A governança ${ }^{1}$ estatal e seu viés de mobilização política, econômica e a relação com o IDH escuda-se no baluarte da soberania para arbitrar (ingerência) investimentos de segurança, todavia, sem observar a população flutuante estrangeira no País e seus efeitos e repercussões transfronteiriços, contrariando, inclusive, os ditames constitucionais.

A falta de previsibilidade e de antecipação ao "risco" de desastre, para adoção de medidas "preventivas" de mitigação efetiva aos efeitos (tais como o mapeamento, inventário, planejamento e ordenação), decorre do foco estatal centrado na "ameaça" (com predominantes ações reativas), por conseguinte, onerando o Estado e as pessoas vulneráveis e ao patrimônio. A modernidade doutrinária e constitucional do Brasil estabeleceu a meta preventiva, estabelecida na temática da "vulnerabilidade", todavia, os resultados cronológicos e concretos demonstram o contrário.

Nesse diapasão, o método empregado é o hipotético-dedutivo, sob a lupa jurídica, confrontando-se analiticamente os fatos concretos ocorridos, os resultados

O termo Governança, etimologicamente, significa "direção" (termo usual na cibernética e nas ciências do controle - dirigir) representa as ações do governo para "descobrir meios de identificar metas e depois identificar os meios para alcançar essas metas". PETERS, Brainard Guy. O que é governança? Revista do TCU, Brasília, n. 127, maio/ago. 2013. Disponível em: https://revista.tcu.gov. br/ojs/index.php/RTCU/article/view/87/85. Acesso em: 20 jun. 2019. 
desses eventos e o cotejo à doutrina e a Lex, com fulcro no acervo bibliográfico interdisciplinar invocado. Por objetivo geral vislumbra-se o conhecimento norteador das teorias do "risco de desastre e da prevenção". No tocante aos objetivos específicos, visa-se o exame da realidade concreta dos desastres em amostragem, especialmente referentes ao rompimento de barragens de rejeitos em Minas Gerais, Brasil, para identificação do procedimento predominante científico adotado ou não pelo governo, por meio de seus órgãos, especialmente de segurança pública, para execução das atividades de defesa civil.

O problema pode ser evidenciado na amostra dos três últimos episódios ocorridos em Minas Gerais, nos rompimentos sucessivos das barragens de rejeitos minerais nos municípios de Mariana e Brumadinho. Estima-se que os atinentes desastres sucessivos eram tecnicamente previsíveis, mas os órgãos responsáveis pela fiscalização e execução de medidas preventivas não o fizeram oportunamente. A responsabilidade de segurança principal era das respectivas pessoas jurídicas (Vale e San Marco - denominados garantidores), mas o Estado, em face das temerárias ações e omissões dos órgãos especializados, "vulnerabilizou" ainda mais as pessoas e patrimônio envolvidos. O paradoxo do "conhecimento" disponível e desprezado pelos órgãos de governo afetos e as consequências sedimentadas demonstraram despreparo e necessidade emergente de alteração estrutural, dentre as quais, a reformulação constitucional e administrativa da prestação da defesa civil (art. 144, caput e "I $5^{\circ}$ Às polícias militares cabem a polícia ostensiva e a preservação da ordem pública; aos corpos de bombeiros militares, além das atribuições definidas em lei, incumbe a execução de atividades de defesa civil.", da CRFB e art. 142, caput e inciso II, da CE/89 - grifou-se), sob pena de reiteração dos eventos catastróficos, combatidos pelos iluministas.

Diante dessa conjuntura, a pesquisa se desenvolve, além da presente introdução, pelos capítulos da: 2) justiça espacial e ambiental, externando o quanto os pobres são discriminados; 3) a gestão de risco, destacando a racionalidade do pensamento de Voltaire e Rousseau e evoluções decorrentes; 4) as amostras de desastres naturais e breves reflexões iluministas; 5) do rompimento de barragens de rejeitos em Minas Gerais, no Brasil; 6) a fiscalização e as atividades de defesa civil e; 7) as considerações finais.

\section{A justiça espacial e justiça ambiental}

Conceitualmente, a temática da justiça ambiental e justiça espacial foram coroadas por pluralidade de eventos discriminatórios e repercussões danosas por fatores adversos, especialmente antrópicos ${ }^{2}$. Ambos os conceitos são análogos, sendo o primeiro vinculado à distribuição geográfica dos efeitos socioambientais ${ }^{3}$, enquanto o segundo destaca o desprestígio pela discriminação da distribuição de oportunidades e seleção econômica da qualidade e efeitos ambientais locais. A corrente da justiça ambiental visa assegurar "igual proteção contra os riscos ambientais em relação às questões de saúde e qualidade de vida" a todas as comunidades, para que desfrutem do direito de viver em um ambiente seguro, independentemente da etnia, sexo, idade ou nível de renda ${ }^{4}$.

O quadro semântico advém de repercussões reflexivas históricas, como os ativismos estadunidenses, destacados na década de 1970, que questionavam situações de racismo ambiental (implicando desigualdade social na distribuição espacial de impactos e riscos ambientais), em que determinados grupos de pessoas eram excluídos pela fragilidade econômica, sendo coagidos às margens geográficas ou espaciais, submetendo-se aos baixos investimentos em saneamento básico, infraestrutura, educação, com estímulos à aglutinação demográfica e de construções informais, à concentração de ambientes insalubres e de risco, como aterros sanitários, dentre outros, especialmente pelo critério étnico racial e econômico ${ }^{5}$.

SCHLOSBERG, David. Reconceiving environmental justice: global movements and political theories. Environmental politics, [S. 1.], v. 13, n. 3, p. 517-540, 2004. Disponível em: https://www. uea.ac.uk/documents/40159/0/hh6-schlosberg-reconceiving-ej2004/6bf17634-9470-4321-82db-7c6c1c5274b8. Acesso em: 21 jun. 2019.

3 MARTÍNEZ, Teresa. "Los geógrafos y la teoría de riesgos y desastres ambientales”. Perspectiva Geográfica, [S. 1.], v. 14, n. 1, p. 241 263, 2009. p. 248. Disponível em: https://dialnet.unirioja.es/servlet/articulo?codigo=3644793. Acesso em: 10 jun. 2019.

4 CAMPOS-VARGAS, Milagros; APARICIO, Alejandra Toscana; ALANÍS, Juan Campos. Riesgos socionaturales: vulnerabilidad socioeconómica, justicia ambiental y justicia espacial. Cuadernos de Geografía, [S. 1.], v. 24, n. 2, p. 53-69, 2015, p. 60. Disponível em: http:// www.scielo.org.co/pdf/rcdg/v24n2/v24n2a4.pdf. Acesso em: 10 jun. 2019.

RAWLS, J., A theory of justice. Cambridge, Mass.: Harvard University Press, 1971.; BULLARD, R. D. Confronting environmental racism: voices from the grassroots. Boston: South End Press, 1993.; BUL- 
Em países de terceiro mundo, de desenvolvimento industrial, surge também o denominado "ambientalismo dos pobres", na proposição do "ambientalismo antroprocêntrico e não antroprocêntrico", em sentido de que o ambientalismo atende aos anseios dos ricos e prejudica os pobres ${ }^{6}$. Consoante Pezzullo e Sandler, os pobres são politicamente marginalizados e sofrem significativamente com os efeitos da degradação ambiental $^{7}$. No mesmo diapasão, a exacerbada injustiça, na visão global do ônus dos impactos ambientais insidem às nações e pessoas mais desprovidas economicamente $^{8}$. Nessa assertiva, a influência, oscilação e migração

LARD, R. D. Dumping in dixie: race, class, and environmental quality. Boulder, Colo.: Westview Press, 1990.; BULLARD, R. D. Unequal protection: environmental justice and communities of color. San Francisco: Sierra Club Books, 1994.; BULLARD, R. D.; WRIGHT, B. H. The quest for environmental equity: mobilizing the african-american community for social Change. In. DUNLAP, R. E.; MERTIG, A. G.(ed.). American environmentalism: the U.S. environmental movement, 1970-1990. New York: Taylor and Francis, 1992. p. 39-49.

6 WENZ, Peter. Does environmentalism promote injustice for the poor? In: SANDLER, Ronald; PEZZULLO, Phaedra C. (ed.). Environmental justice and environmentalism the social justice challenge to the environmental movement. Cambridge: MIT, 2007. p. 57-84. p. 58. Disponível em: http://comphacker.org/comp/engl338/files/2012/08/ Environmental-Justice-and-Environmentalism-The-Social-JusticeChallenge-to-the-Environmental-Movement-Ronald-Sandler-andPhaedra-C.-Pezzullo.pdf. Acesso em: 20 jun. 2019.; MARTÍNEZALIER, Joan. El ecologismo de los pobres: conflictos ambientales y lenguajes de valoración. 5. ed. Barcelona: Icaria, 2011.

PEZZULLO, Phaedra C.; SANDLER, Ronald. Introduction: Revisiting the Environmental Justice Challenge to Environmentalism. In: PEZZULLO, Phaedra C.; SANDLER, Ronald (ed.). Environmental justice and environmentalism the social justice challenge to the environmental movement. Cambridge: MIT, 2007. p. 1-24. p. 17. Disponível em: http://comphacker.org/comp/engl338/files/2012/08/Environmental-Justice-and-Environmentalism-The-Social-JusticeChallenge-to-the-Environmental-Movement-Ronald-Sandler-andPhaedra-C.-Pezzullo.pdf. Acesso em: 20 jun. 2019.; SANDLER, Ronald (ed.). Environmental justice and environmentalism the social justice challenge to the environmental movement. Cambridge: MIT, 2007. p. 285-308. Disponível em: http://comphacker.org/comp/engl338/ files/2012/08/Environmental-Justice-and-Environmentalism-TheSocial-Justice-Challenge-to-the-Environmental-Movement-RonaldSandler-and-Phaedra-C.-Pezzullo.pdf. Acesso em: 21 jun. 2019.

8 ROBERTS, J. Timmons. Globalizing environmental justice. In: PEZZULLO, Phaedra C.; SANDLER, Ronald (ed.). Environmental justice and environmentalism the social justice challenge to the environmental movement. Cambridge: MIT, 2007. p. 285-308. Disponível em: http://comphacker.org/comp/engl338/files/2012/08/Environmental-Justice-and-Environmentalism-The-Social-Justice-Challenge-to-the-Environmental-Movement-Ronald-Sandler-and-Phaedra-C.-Pezzullo.pdf. Acesso em: 20 jun. 2019.; SCHLOSBERG, David. Reconceiving environmental justice: global movements and political theories. Environmental politics, [S.1.], v. 13, n. 3, p. $517-$ 540, 2004. p. 521. Disponível em: https://www.uea.ac.uk/documents/40159/0/hh6-schlosberg-reconceiving-ej-2004/6bf176349470-4321-82db-7c6c1c5274b8. Acesso em: 21 jun. 2019. global da econômica e da relação de impactos e desprestígios ambientais, marginalizam os pobres?.

Nesse contexto, a justiça ambiental, que hodiernamente abarca a justiça espacial, o ambientalismo dos pobres, o racismo ambiental, representa a abordagem sistemática de avaliação socioambiental de mensuração dos impactos ambientais e níveis de influência econômicas na elitização e marginalização geopolítica, balizando a aproximação ou o distanciamento do meio ambiente ecologicamente equilibrado, no local de amostragem indicado (região, nação ou continente). A justiça ambiental especifica que grupos raciais ou étnicas, ou famílias com baixa renda econômica, estão muito mais expostos a uma série de problemas e riscos ambientais do que os grupos com maior perfil socioeconômico ${ }^{10}$. Assim, conforme a linhagem do justiça ambiental visa à garantia de estudos de impacto ambiental e respectiva distrivuição equânime dos riscos ${ }^{11}$.

A justiça ambiental está dividida em quatro filamentos básicos ${ }^{12}$. A primeira é a distributiva, destacando o foco na igualdade de tratamento e distribuilçao de bens, serviços e oportunidades. A segunda clivagem é de cunho processual, que infere tomada de decisão isenta, racional, quânine e participativa. A corretiva refere-se à escorreita punição aos desvios de comportamento, enquanto a social vislumbra a agregação do knowhow étnico, cultural e econômico e ameaças políticas em detrimento do meio ambiente ecologicamente equilibrado. Nessa seara, o índice de Desenvolvimento Humano (IDH) de cada País, conforme classificação do Programa de Desenvolvimento das Nações Unidas (UNDP) ${ }^{13}$, é um referencial potencial de balizamento

MARTINEZ-ALIER, Joan; TEMPER, Leah; BENE, Daniela Del; SCHEIDEL, Arnim. Is there a global environmental justice movement?. The Journal of Peasant Studies, [S.1.], v. 43, n. 3, p. 731755, 2016. Disponível em: https://www.researchgate.net/publication/301694370_Is_there_a_global_environmental_justice_movement/download. Acesso em: 21 jun. 2019.

10 CAMPOS-VARGAS, Milagros; APARICIO, Alejandra Toscana; ALANÍS, Juan Campos. Riesgos socionaturales: vulnerabilidad socioeconómica, justicia ambiental y justicia espacial. Cuadernos de Geografía, [S.l.], v. 24, n. 2, p. 53-69, 2015. p. 60. Disponível em: http://www.scielo.org.co/pdf/rcdg/v24n2/v24n2a4.pdf. Acesso em: 10 jun. 2019.

11 FISCHHOFF, Baruch P; KADVANY, John A. Riesgo: una breve introducción. Madrid: Alianza, 2013.

12 KUEHN, Roberth R. A taxonomy of environmental justice. Environmental Law Reporter, [S. 1.], v. 30, p. 10681-10703, 2000. Disponível em: https://ir.lib.uwo.ca/cgi/viewcontent. cgi?article $=1137 \&$ context $=$ aprci. Acesso em: 20 jun. 2019.

13 UNITED NATIONS DEVELOPMENT PROGRAMME. 
da "vulnerabilidade das pessoas e do patrimônio, como demonstram os efeitos traumáticos dos eventos catastróficos ocorridos nos últimos anos".

\section{A gestão do risco}

As calamidades mundiais contemporâneas afloram razões para fomento das pesquisas e parametrização de riscos e demandadas gestões, especialmente preventivas a eventos danosos ${ }^{14}$. Historicamente, várias catástrofes assolaram o mundo, mas uma das pioneiras em relevância científica de época refere-se ao episódio de um terremoto ocorrido em 1 de novembro de 1755, na cidade de Lisboa, gerando a destruição parcial da cidade, por meio de incêndios e outras conjugações, tendo como saldo negativo entre 10.000 e 70.000 mortes $^{15}$.

Diante do trágico evento, Voltaire e Rousseau inovaram e refutaram a proposição da época de atribuir a culpa do evento à divindade ou à natureza, mas sim ao homem, ser racional, capaz de interpretar o ambiente, sazonalidade e outros fatores, para mitigarem os efeitos trágicos ${ }^{16}$. Assim, a visão de risco tinha como leme a "ameaça" (potencial traumático do fenômeno) e foi substituído pela locução da "vulnerabilidade" (capacidade de resposta e subsistência ao evento), uma vez que a racionalidade humana poderia prever e interpretar possíveis eventos e oportunamente estabelecer medidas preventivas mitigadoras. A partir dessas reflexões filosóficas, doutrinariamente, a prevenção passou a ocupar o patamar privilegiado na gestão de riscos. As ações

Human development indices and indicators 2018. UNDP, 29 Feb. 2019. Disponivel em: http://www.br.undp.org/content/brazil/pt/home/ library/idh/relatorios-de-desenvolvimento-humano/relatorio-dodesenvolvimento-humano-2018.html. Acesso em: 26 jul. 2019.

14 CAMPOS-VARGAS, Milagros; APARICIO, Alejandra Toscana; ALANÍS, Juan Campos. Riesgos socionaturales: vulnerabilidad socioeconómica, justicia ambiental y justicia espacial. Cuadernos de Geografía, [S. 1.], v. 24, n. 2, p. 53-69, 2015. Disponível em: http:// www.scielo.org.co/pdf/rcdg/v24n2/v24n2a4.pdf. Acesso em: 10 jun. 2019.

15 BÖHME, Gernot; BÖHME, Hartmut. Fuego, agua, tierra, aire: una historia cultural de los elementos. Barcelona: Herder, 1996.

16 AROUET, François-Marie [pseudônimo - Voltaire]. Poemes sur le désastre de Lisbonne at sur la loi naturalle, avec des prefates des notes, [...]. Paris: Galica, 1756. Disponível em: https://gallica.bnf.fr/ark:/12148/ bpt6k5727289v/f9.image. Acesso em: 25 jul. 2019.; ROUSSEAU, Jean-Jacques. Carta de Rousseau a Voltaire sobre a providência. Tradução e aparato crítico de Maria das Graças de Souza. In: MENEZES, Edmilson (org.). História e providência: Bossuet, Vico e Rousseau. Ilhéus: Editus, 2006. reativas ou curativas passaram a segundo plano. Nessa seara de concepção e dimensionamento do risco e consequências do desastre, a "ameaça" de fatores adversos foi substituída pela "vulnerabilidade" humana e ambiente, como efeito do nível de planejamento humano.

Figura 1 - Evolução da teoria do risco

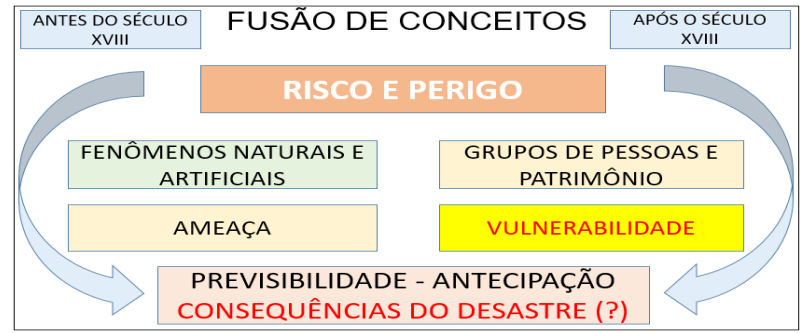

Fonte: Elaborada pelos autores (2019).

Entretanto, as ocorrências registradas comprovam que a arcaica visão do risco estabelecido na ameaça e nas ações reativas, em detrimento das comunidades vulneráveis, ainda é vigente nos dias atuais, especialmente no Brasil ${ }^{17}$. Evolutivamente, a corrente anglo-saxônica "da ecologia humana", da escola de Chicago retomou a discussão ao final do seculo XIX e XX, com fulcro interdisciplinar das ciências sociológicas, ratificando a relação do ser humano com o ambiente natural, sob um contexto ambiental ${ }^{18}$. Outrossim, o risco assumiu a roupagem sociocultural, em relação à sociedade (antrópica) e o ambiente natural, gerando situações propensas aos desastres, como aditivo de impulsão aos fenômenos naturais e artificiais.

Assim, sedimentou-se a doutrina de aglutinação dos riscos naturais e dos riscos humanos e ambientais, suscitando a conexão do conhecimento geográfico do local e do seu contexto à vulnerabilidade social ${ }^{19}$. Destarte,

17 BECKER, Evaldo; BECKER, Michele Amorim. Contribuições de Rousseau ao entendimento dos desastres socioambientais contemporâneos. Trans/Form/Ação, Marília, v. 37, n. 2, p. 111-126, maio/ago. 2014. Disponível em: http://www.scielo.br/pdf/trans/ v37n2/06.pdf. Acesso em: 25 jul. 2019.

18 CAMPOS-VARGAS, Milagros; APARICIO, Alejandra Toscana; ALANÍS, Juan Campos. Riesgos socionaturales: vulnerabilidad socioeconómica, justicia ambiental y justicia espacial. Cuadernos de Geografía, [S. 1.], v. 24, n. 2, p. 53-69, 2015. p. 55. Disponível em: http:// www.scielo.org.co/pdf/rcdg/v24n2/v24n2a4.pdf. Acesso em: 10 jun. 2019.

19 MARTÍNEZ, Teresa. 2009. "Los geógrafos y la teoría de riesgos y desastres ambientales". Perspectiva Geográfica, [S. 1.], v. 14, n. 1, p. 241-263. p. 248. Disponível em: https://dialnet.unirioja.es/servlet/articulo?codigo=3644793. Acesso em: 10 jun. 2019.; BECKER, Evaldo; BECKER, Michele Amorim. Contribuições de Rousseau ao entendimento dos desastres socioambientais contemporâneos. Trans/Form/Ação, Marília, v. 37, n. 2, p. 111-126, maio/ago. 2014. 
tanto os riscos, como os desastres, assumem uma dimensão global, com origem nas características da sociedade ("pressões dinâmicas" do crescimento populacional, urbanização e densificação, degradação ambiental, falta de ética e outros) ${ }^{20}$, emergidas em crises ambientais. Esses vetores decorrem da exploração irracional dos recursos naturais disponíveis, mudanças climáticas, poluição e deterioração da biota, sem o planejamento efetivo, como os efeitos e esquemas de produção dos países desenvolvidos, por força de interesses econômicos, políticos e culturais ${ }^{21}$.

Desde então, a vulnerabilidade passou a ser a chave para a compreensão dos desastres (afastando-se a proposição da ameaça) ${ }^{22}$. Assim, o desastre que era um evento produzido por um fenômeno natural passou a incorporar então o elemento antrópico. Nessas premissas, reitera-se, a temática do risco de desastre aborta a previsão de ameaça e recepciona efetivamente o quesito da vulnerabilidade, balizada pelos níveis estruturais de respostas preventivas e efetivas de mitigação de seus efeitos, como as "condições de insegurança", a fragilidade social e a pobreza, entre outras ${ }^{23}$. Nesse consórcio,

Disponível em: http://www.scielo.br/pdf/trans/v37n2/06.pdf. Acesso em: 25 jul. 2019.; CAMPOS-VARGAS, Milagros; APARICIO, Alejandra Toscana; ALANÍS, Juan Campos. Riesgos socionaturales: vulnerabilidad socioeconómica, justicia ambiental y justicia espacial. Cuadernos de Geografía, [S. 1.], v. 24, n. 2, p. 53-69, 2015. p. 56. Disponível em: http://www.scielo.org.co/pdf/rcdg/v24n2/ v24n2a4.pdf. Acesso em: 10 jun. 2019.

20 UNITED NATIONS DEVELOPMENT PROGRAMME. Human development indices and indicators 2018. UNDP, 29 Feb. 2019, Disponível em: http://www.br.undp.org/content/brazil/pt/home/ library/idh/relatorios-de-desenvolvimento-humano/relatorio-dodesenvolvimento-humano-2018.html. Acesso em: 26 jul. 2019.

21 MARTÍNEZ-ALIER, Joan. El ecologismo de los pobres: conflictos ambientales y lenguajes de valoración. 5. ed. Barcelona: Icaria, 2011. 22 BERROCAL VARGAS, Milena. Análisis y evaluación de la vulnerabilidad de la población de la Fortuna de San Carlos a la actividad volcánica del volcán Arenal. 2008. Tesis (Doctorado) - Universidad de Girona, Costa Rica, San José, 2008.; CAMPOS-VARGAS, Milagros; APARICIO, Alejandra Toscana; ALANÍS, Juan Campos. Riesgos socionaturales: vulnerabilidad socioeconómica, justicia ambiental y justicia espacial. Cuadernos de Geografía, [S. 1.], v. 24, n. 2, p. 53-69, 2015. p. 57. Disponível em: http://www.scielo.org.co/pdf/rcdg/v24n2/ v24n2a4.pdf. Acesso em: 10 jun. 2019.

23 RAWLS, J. A theory of justice. Cambridge, Mass: Harvard University Press, 1971.; BULLARD, R. D. Confronting environmental racism: voices from the grassroots. Boston: South End Press, 1993.; BULLARD, R. D. Dumping in Dixie: race, class, and environmental quality. Boulder, Colo.: Westview Press, 1990.; BULLARD, R. D. Unequal protection: environmental justice and communities of color. San Francisco: Sierra Club Books, 1994.; BULLARD, R. D., WRIGHT, B. $\mathrm{H}$. The quest for environmental equity: mobilizing the african-american community for social change. In: DUNLAP, R. E.; MERTIG, A. G. (ed.). American environmentalism: the U.S. environmental movement, a pesquisa de Eiras $^{24}$ apresenta o esquema de Cerri ${ }^{25}$, abrangendo a classificação dos riscos ambientais de natureza geológica e hidrológica, pontuando a questão da vulnerabilidade, em sintonia aos estudos avançados nos EUA, ipsis:

Figura 2- Gênese dos risco

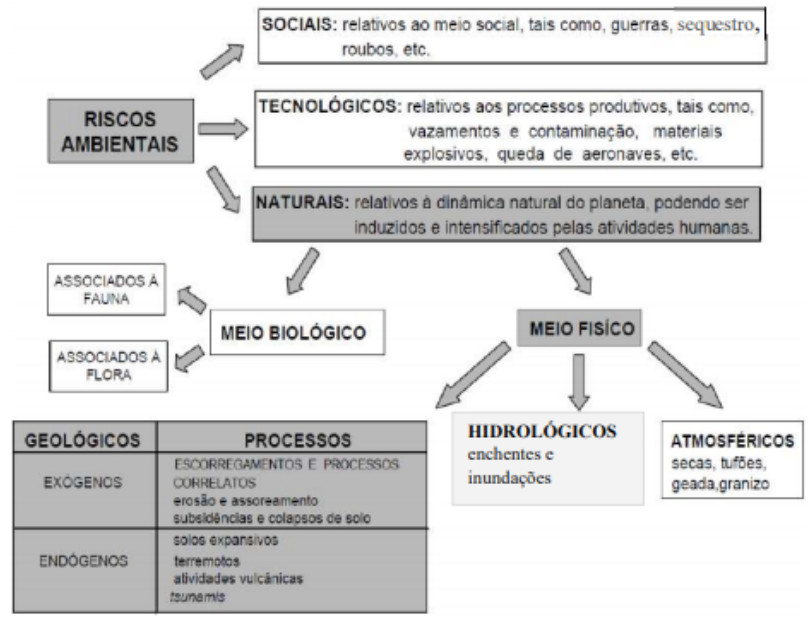

Fonte: Cerri (1993).

A temática da gestão de risco e perigo de desastres (ou catástrofes) é essencial e deve ser celebrada de forma interdisciplinar, multiplicando-se as linhas de ações e a agregação de conhecimento técnico nas suas diversas fases, à ilustração da afinidade dos ramos da geografia, antropologia, sociologia, economia e ecologia política, dentre outras ${ }^{26}$. Nesse concerto, várias perspectivas

1970-1990. New York: Taylor and Francis, 1992. p. 39-49.

${ }^{24}$ EIRAS, Cahio Guimarães Seabra. Mapeamento de suscetibilidade a eventos perigosos de natureza geológica e bidrológica em São Carlos - SP. 2017. Dissertação (Mestrado) - Escola de Engenharia de São Carlos, da Universidade de São Paulo, São Carlos, 2017. p. 45. Disponível em: http://www.teses.usp.br/teses/disponiveis/18/18132/tde01032018-095311/en.php. Acesso em: 29 jun. 2019.

25 CERRI, Leandro Eugenio Silva. Riscos geológicos associados a escorregamentos: uma proposta para a prevenção de acidentes, 1993. Tese (Doutorado) - UNESP, Rio Claro-SP, 1983.

26 MARTINEZ-ALIER, Joan; TEMPER, Leah; BENE, Daniela Del; Arnim Scheidel. Is there a global environmental justice movement?. The Journal of Peasant Studies, [S.l.], v. 43, n. 3, p. 731755, 2016. Disponível em: https://www.researchgate.net/publication/301694370_Is_there_a_global_environmental_justice_movement/download. Acesso em: 21 jun. 2019.; LOURENÇO, Luciano Fernandes. Riscos e catástrofes programa, conteúdos e métodos de ensino. Universidade de Coimbra, 2007. p. 45. Disponível em: https:// www.uc.pt/fluc/nicif/Publicacoes/Estudos_de_Colaboradores/ PDF/Relatorios/2007_Riscos_e_cata_strofes.pdf. Acesso e em: 29 jun. 2019.; LAVELL, Allan. La gestión local del riesgo: nociones y precisiones en torno al concepto y la práctica. Guatemala: Centro de Coordinación para la Prevención de los Desastres Naturales en América Central (CEPREDENAC), 2003. 
científicas são festejadas, como a relevância da gestão de risco à tomada de decisão em favor da segurança humana e ambiental, o mapeamento social do risco, as perspectivas socionaturais do perigo, as interações socioeconômicas ${ }^{27}$, dentre outras facetas, como fatores de risco.

Nessa sintonia, à proposição de $\mathrm{Verde}^{28}$, ou da Occupational Health ans Safety (OHSAS) ${ }^{29}$ e do glossário de Defesa Civil ${ }^{30}$, há convergência e versatilidade na uniformidade metodológica e viabilização do entendimento conceitual, dinamizando-se avaliações de risco global, com aplicação ampla à gestão de todas as organizações (industrias, comércio, instituições públicas e outras $^{31}$. Em convenção técnica, na proposição do Sistemas de Gestão da Saúde e da Segurança do Trabalho, a OHSAS e o atinente glossário preconizam conceitos e, no que couber definições, basicamente uniformes.

Os conceitos mais demandados nos atinentes postulados são os de "perigo, risco, desastre, catástrofe (ou calamidade), ameaça, vulnerabilidade e prevenção". O risco é a condição necessária ou "prelúdio" para um desastre, portanto, uma dedução lógica decorrente de informações técnicas de potencial ocorrência de fenômeno natural ou artificial (de grande repercussão — desastre de classe mais elevada ou catástrofe), que, ao ser iniciado gera a situação de perigo (qualquer condição potencial ou real imediatas que pode vir a causar morte, ferimento ou dano ao patrimônio). O "desastre", geralmente pode ser categorizado em até quatro classificações (patamares I, II, III e IV, sendo este, por sua relevante proporcionalidade, considerado também como catástrofe ou calamidade), segundo a dimensão dos da-

${ }^{27}$ SCHUBERT, Kirsten; GEBAUER, Thomas. The creeping disaster: global health in crisis. In: WORLDRISKREPORT 2013. Lars jeschonnek e mediacompany, Bonn, 2013. p. 34-44. Disponível em: https://collections.unu.edu/eserv/UNU:2018/WorldRiskReport_2013_online_01.pdf. Acesso em: 10 ago. 2019.

28 VERDEL, Tierry. Méthodologies d'évaluation globale des risques: applications potentielles au génie civil. [S. 1: s. n.], 2005.

29 OCCUPATIONAL HEALTH ANS SAFETY ASSESSMENTS SERIES. OHSAS180012007. Sistema de gestão de segurança e saúde ocupacional [Trad. LS2007R1]. British Standards Institution, 2007. Disponível em: https:/ / comum.rcaap.pt/bitstream/10400.26/7319/2/ Anexo\%20I\%20OHSAS180012007_pt.pdf. Acesso em: 30 jun. 2019.

30 BRASIL. Ministério do Planejamento e Orçamento. Glossário de Defesa Civil estudos de riscos e medicina de desastres. Imprensa Nacional, Brasília, 1998. Disponível em: http://www.defesacivil. mg.gov.br/images/documentos/Defesa\%20Civil/manuais/GLOSSARIO-Dicionario-Defesa-Civil.pdf. Acesso em: 30 jun. 2019.

31 VERDEL, Tierry. Méthodologies d'évaluation globale des risques: applications potentielles au génie civil. [S. 1: s. n.], 2005. nos, prejuízos e magnitudes da nocividade às pessoas e ao patrimônio. Portanto, seja natural ou artificial, o desastre decorre de um evento esporádico, de grande potencial destrutivo em pequeno lapso de tempo, impactando comunidades vulneráveis ${ }^{32}$. Já a catástrofe, termo sinônimo de calamidade, etimologicamente advém da aglutinação dos radicais gregos kata (para baixo) e strophe (virar), strophein, virada de expectativas ${ }^{33}$, correspondendo, então, a desastres de grande repercussão (nível 4), lastreada por considerável número de mortos, feridos e destruição (trata-se de ocorrência eventual funesta e lastimosa).

No contesto dos termos "ameaça e vulnerabilidade", o primeiro representa o potencial de efeitos traumáticos de determinado cenário de risco ou perigo, enquanto o segundo corresponde ao nível de capacidade de resposta e proteção das pessoas e patrimônios envolvidos. $\mathrm{Na}$ atualidade a relevância da vulnerabilidade é superlativa à questão da ameaça (secundária), no âmbito da ciência da gestão de risco. Nesse sentido, foram divulgados, pela revista WorldRiskIndex 2013, os 15 países mais susceptíveis pela pobreza (elevado nível de pobreza e seus reflexos à saúde, bem-estar e dignidade), e desastres, com a renda per capta de sobrevivência, de seus habitantes, de 1,25 USD ${ }^{34}$ por dia, além dos 15 países com menor capacidade de enfrentamentos e vulnerabilidade e respectivos percentuais ${ }^{35}$ :

32 RUTHERFORD, W.H.; BOER, J. The definition and classification of disasters. Injury, [S.1.], v. 15, p. 10-12, 1983.; BENSON, C.; CLAY E. J. Disasters, vulnerability and the global economy. In: KREIMER, A.; ARNOLD, M. (ed.). The future disaster risk: building safer cities. Washington, D. C. 2003. (Disaster Risk Management Series n. 3). p. 3-32 33 JUSTO FILHO, João Francisco; PIQUEIRA, José Roberto Castilho. Engenharia das catástrofes: entre o determinístico e o imponderável. Estudos avançados, São Paulo, v. 27, n. 77, 2013. Disponível em: http://www.scielo.br/pdf/ea/v27n77/v27n77a13.pdf. Acesso em: 25 jun. 2019.

34 USD corresponde ao dólar dos EUA.

35 WELLE, Torsten; BIRKMANN, Jörn; RHYNER, Jakob, WITTING, Maximilian, WOLFERTZ, Jan. WorldRiskIndex 2013, In: WORLDRISKREPORT 2013. Lars Jeschonnek e MediaCompany, Bonn, p. 45-56, 2013. p. 50-53. Disponível em: https://web.archive. org/web/20140816173655/http://www.worldriskreport.com/uploads/media/WorldRiskReport_2013_online_01.pdf\#. Acesso em: 20 jun. 2019. 
Figura 3 - Classificação pelo nível de vulnerabilidade

\begin{tabular}{|c|c|c|c|}
\hline \multirow{17}{*}{$\begin{array}{l}\text { Deficiência } \\
\text { financeira }\end{array}$} & \multicolumn{3}{|c|}{$\begin{array}{l}\text { The } 15 \text { countries with the highest susceptibility } \\
\text { worldwide: }\end{array}$} \\
\hline & Country & Susceptibility (\%) & ) Rank \\
\hline & Madagascar & 67.42 & 1 \\
\hline & Mozambique & 65.54 & 2 \\
\hline & Tanzania & 65.05 & 3 \\
\hline & Liberia & 64.05 & 4 \\
\hline & Chad & 63.62 & 5 \\
\hline & Zambia & 62.94 & 6 \\
\hline & Eritrea & 62.98 & 7 \\
\hline & Burundi & 62.50 & 8 \\
\hline & Haiti & 61.64 & 9 \\
\hline & Niger & 61.26 & 10 \\
\hline & Sierra Leone & 60.68 & 11 \\
\hline & Central African Republic & 60.01 & 12 \\
\hline & Comoros & 59.98 & 13 \\
\hline & Zimbabwe & 58.12 & 14 \\
\hline & Ethiopia & 57.24 & 5 \\
\hline \multirow{17}{*}{$\begin{array}{l}\text { Falta de } \\
\text { enfrentamento }\end{array}$} & \multicolumn{3}{|c|}{$\begin{array}{l}\text { The } 15 \text { countries with the highest lack of } \\
\text { coping capacities worldwide }\end{array}$} \\
\hline & Country & \multicolumn{2}{|c|}{ Lack of C.C.(\%) } \\
\hline & Afghanistan & & 93.44 \\
\hline & Sudan & & 92.42 \\
\hline & Chad & & 91.62 \\
\hline & Zimbabwe & & 89.64 \\
\hline & Haiti & & 89.63 \\
\hline & Yemen & & 89.50 \\
\hline & Guinea & & 89.39 \\
\hline & Myanmar & & 89.11 \\
\hline & Iraq & & 88.92 \\
\hline & Central African Republic & & 88.62 \\
\hline & Burundi & & 88.06 \\
\hline & Guinea-Bissau & & 87.99 \\
\hline & Nigeria & & 87.67 \\
\hline & Eritrea & & 87.44 \\
\hline & Côte d'Ivoire & & 87.13 \\
\hline & $\begin{array}{l}\text { The } 15 \text { countries with the } \\
\text { worldwide }\end{array}$ & highest vuln & nerability \\
\hline & Country & Vuln & n. $(\%)$ \\
\hline & Afghanistan & & 5.41 \\
\hline & Chad & & 4.28 \\
\hline & Eritrea & & 4.23 \\
\hline & Niger & & 3.21 \\
\hline & Haiti & & 3.05 \\
\hline geral & Sierra Leone & & 0.75 \\
\hline & Liberia & & 0.31 \\
\hline & Central African Republic & & 9.98 \\
\hline & Mozambique & & 9.85 \\
\hline & Guinea & & 9.20 \\
\hline & Madagascar & & 9.18 \\
\hline & Burundi & & 9.17 \\
\hline & Nigeria & & 8.99 \\
\hline & Mali & & 8.90 \\
\hline & Comoros & & 8.56 \\
\hline
\end{tabular}

Fonte: Welle (et al., 2013, p. 50).

Após as considerações conceituais preliminares, destaca-se o anseio de maior relevância da pesquisa, a expressão "prevenção", que vincula e açambarca o mapeamento, inventário, planejamento e ordenação para mitigação dos efeitos dos desastres. Trata-se, pois, de medidas antecipadas, consentâneas e oportunas, que visam minimizar os previsíveis os riscos e perigos de desastres, mitigar e vulnerabilidades e os efeitos traumáticos, em especial, maximizar a segurança e a integridade das pessoas e do patrimônio (inclusive ambiental), alvos do estimado evento.

A gestão de risco de desastres decorre da ciência cindínica, termo que advém do francês "cyndinique", correspondendendo ao método fundamentado na visão de hiperespaço de perigo. Estas ciências visam o mapeamento das situações de risco, o inventario das vulnerabilidades, o planejamento adequado de mitigação dos efeitos dos desastres e a regulamentação do comportamento dos atores, procedimentos cabíveis de mecanismos preventivos ${ }^{36}$. (diante da situação de vulnerabilidade e perígo, em dado tempo e espaço, antecipadamente). As ciências que estudam os riscos naturais e humanitários devem interargir, como explanou objetivamente Jean-François Brilhac ${ }^{37}$. Diante do método de Kervern e Rubise, com as adequações evolutivas da engenharia, para fins de mensuração da situação fática concreta, investimentos do estado e resultados almejados e alcançados, chega-se à pertinente síntese ${ }^{38}$ :

36 HERBERT, D. T.; MATTHEWS, J. A. Geography: roots and continuities. In: MATTHEWS, J. A.; HERBERT, D.T. (org.). Unifying geography: common heritage, shared future. London: Routledge, 2004. p. 3-20.; MARCELINO, E. V., NUNES, L. H., KOBIYAMA, M. Mapeamento de risco de desastres naturais do estado de Santa Catarina. Caminhos da Geografia (UFU), Uberlândia, v. 7, n. 17, p. 72-84, 2006. Disponível em: http://www.seer.ufu.br/index.php/ caminhosdegeografia/article/download/15273/8574. Acesso em: 22 ago. 2019.

37 BRILHAC, Jean-François. Le concept des cyndiniques. Paris: UVED, 2019. Disponível em: https://ressources.uved.fr/Grains_Module3/ Cyndiniques/site/html/Cyndiniques/Cyndiniques.html. Acesso em: 30 jun. 2019.

38 KERVERN, G. Y.; RUBISE, P. L'archipel du danger. Economica, 1991.; KERVERN, G. Y. Eléments fondamentaux des cindyniques. Economica, 1995.; VERDEL, Tierry. Méthodologies d'évaluation globale des risques: applications potentielles au génie civil. [S. 1: s. n.], 2005. 
Figura 4 - Hiperespaço do perigo e suas dimensões

\begin{tabular}{|c|c|}
\hline $\begin{array}{c}\text { Hiperespaço } \\
\text { do Perigo }\end{array}$ & Te \\
\hline $\begin{array}{c}\text { Cinco } \\
\text { Dimensões }\end{array}$ & $\begin{array}{l}\text { Fática ou epistêmica - memórias armazenadas } \\
\text { sobre desastres antigos; } \\
\text { Estatísticas ou de representações - dados para } \\
\text { mensuração dos riscos; } \\
\text { Finalidade: a cada uma das Redes (pessoas ou } \\
\text { grupos); } \\
\text { Deontológica - regulação normativa } \\
\text { comportamental; } \\
\text { Axiológica - sistema de valores fundamentais. }\end{array}$ \\
\hline
\end{tabular}

Fonte: Brilhac (2012), adaptado pelos autores.

Nessa senda, o perigo é extraído do déficit de cada uma das cinco dimensões (ou déficit sistêmico cindinogênico) e das contradições entre essas dimensões (disjunções) e dissonâncias entre dois ou mais grupos de atores $^{39}$. Esses déficits, após os eventos de catástrofes, são catalogados em três categorias, quais sejam, déficits "culturais" de infalibilidade, simplismo, não-comunicação e autoajuda; déficits "organizacionais" de subordinação da segurança e outras funções criadoras de risco e a diluição de responsabilidade; déficits "gerenciais" pela falta de feedback, falta de formalidades burocráticas de controle, ausência de treinamento de pessoal, fragilidade de preparação para momentos de crise. Ilustrando a questão, na temática do "arquipélago do perigo", traz à baila exemplos singulares, como: "desastre de Bhopal em dezembro de 1984, acidente com o ônibus espacial Challenger em janeiro de 1986 e desastre de Chernobyl em abril de 1986", destacando vários déficits sistêmicos cindinogênicos ${ }^{40}$.

Conforme os postulados modernos da Teoria do Risco, a governança do Estado, detentora da expressão da soberania ${ }^{41}$, é a parte legitimada para agir preventivamente, minimizar os riscos e maximizar a segurança das

\footnotetext{
39 VERDEL, Tierry. Méthodologies d'évaluation globale des risques: applications potentielles au génie civil, 2005.

40 KERVERN, G. Y. Eléments fondamentaux des Cindyniques. Economica, 1995.

41 SÓLON, Ari Marcelo. Teoria da soberania como problema da norma jurídica e da decisão. Porto Alegre: Fabris, 1997.
}

pessoas e do patrimônio. Os mesmos órgãos responsáveis pelas atividades reativas, em caso de situações de risco e de desastres. Entretanto, os resultados auferidos, quantitativo, qualitativo ou aglutinando ambos, em dado lapso temporal, são indicadores do nível de eficiência, eficácia e efetividade ${ }^{42}$ da prestação estatal. Essas competências jurídicas e técnicas, seja no modelo anglo-saxão ou weberiano, são atribuídas, constitucionalmente, por afinidade e por representação do braço forte do Estado, aos órgãos de segurança pública ou afins.

No Brasil, a "segurança pública" está estabelecida nos baluartes da preservação da ordem e da preservação da incolumidade pública das pessoas e do patrimônio, sob o escudo estratégico da "soberania nacional" e do povo, portanto, fundamentado no interesse público e no sine qua nom bem comum de todos (sem a segurança pública não há, sequer, que aventar em segurança jurídica, estabilidade econômica, socioambiental, dentre outras) ${ }^{43}$. A malha de sustentação da segurança pública está na soberania, decorrente do "plus" e na combinação dos art. $1^{\circ}$, inciso I e parágrafo único, art. $4^{\circ}$, incisos I, III, IV e V, art. 14, caput, art. 18, art. 144, caput e "s $5^{\circ}$ Às polícias militares cabem a polícia ostensiva e a preservação da ordem pública; aos corpos de bombeiros militares, além das atribuições definidas em lei, incumbe a execução de atividades de defesa civil."'(grifou-se), da Constituição da República Federativa do Brasil $(\mathrm{CRFB})^{44}$. Outrossim, há pacífica sedimentação doutri-

42 É com base nesse sistema de indicadores que o avaliador de projetos sociais cumpre o papel que lhe é devido, que é o de informar sobre o desempenho dos projetos, desempenho este que deve abarcar informações sobre a utilização dos recursos financeiros e materiais - eficiência; sobre o alcance dos objetivos e metas previamente estabelecidos - eficácia e, ainda, sobre a capacidade dos resultados do projeto de produzir mudanças significativas e duradouras - efetividade. FRASSON, Ieda. Critérios de eficiência, eficácia e efetividade adotados pelos avaliadores de instituicões não-governamentais financiadoras de projetos sociais. 2001. Dissertação (Mestrado em Engenharia de Produção) - Universidade Federal de Santa Catarina, Florianópolis, 2001, p. 298. Disponível em: https://repositorio.ufsc. $\mathrm{br} /$ bitstream $/$ handle $/ 123456789 / 82184 / 175094$. pdf? sequence $=1$. Acesso em: 20 jun. 2019.

43 OLIVEIRA, Edson Rodrigues. A competência constitucional do Corpo de Bombeiros Militar para atuação na proteção ambiental. 2017. Dissertação (Mestrado em Direito) - Escola Superior Dom Helder Câmara, Belo Horizonte, 2017, p. 80. Disponível em: http://www. domhelder.edu.br/mestrado/editor/assets/arquivos_dissertacoesd efendidas/890a58fa5dbb6d35e38619b40dd232c8.pdf. Acesso em: 4 maio 2019.

44 BRASIL. [Constituição (1988)]. Constituição da República Federativa do Brasil de 1988. Brasília, DF: Presidência da República, [2018]. Disponível em: http://www.planalto.gov.br/ccivil_03/Constituicao/Constituição.htm. Acesso em: 1 jun. 2019. 
nária dentre diversos autores ${ }^{45}$. Enquanto a União goza da "soberania" e da autonomia, em determinadas matérias legais, os demais entes federativos, nos limites constitucionais, exercem, apenas, a restrita "autonomia".

Nessa sintonia sistêmica, apesar da territorialidade dos estados, a segurança pública não se limita à autonomia circunscricional, pois está estabelecida na chancela da soberania nacional, sob a competência originária da União, agindo nos estabelecimentos federais e até de forma externa ao estado, especialmente em divisas, pois atuará quem está mais próximo, comunicando-se, oportunamente, a demanda extraordinária ao órgão competente da segurança pública local, para adoção das medicas oportunas cabíveis. Em representação dissertativa de mestrado em direito ambiental ${ }^{46}$, houve a fusão da fundamentação da competência Constitucional das Instituições Militares Estaduais e as afinidades com as atividades de proteção ambiental, e relação da soberania e autonomia, emergindo-se o ramo da segurança pública ambiental, ipsis litteris:

\footnotetext{
45 COSTA, Beatriz Souza; OLIVEIRA, Edson Rodrigues de. O patamar hierárquico da Resolução Conama: uma Análise pelos óculos da Ação Direta de Inconstitucionalidade 3.074 e holofotes da soberania repúblicana e autonomia dos entes federativos. Revista Argumentum, (RA), Marília, v. 16, p. 209-232, 2015. p. 218, 219. Disponível em: http://ojs.unimar.br/index.php/revistaargumentum/ article/view/155. Acesso em: 20 mar. 2016.; PIMENTA, Marcelo Vicente de Alkimim. Teoria da constituição. Belo Horizonte: Del Rey, 2007. p. 20, 24, 28.; CASTILHO, Ricardo. Estado: elementos constitutivos, conceito, objetivos e tipos. In: RAMOS, Dircêo Torrecillas. O federalista atual: teoria do federalismo. Belo Horizonte: Arraes, 2013. p. 2-34. p. 6, 8.; OLIVEIRA, Márcio Luís de. A Constituição juridicamente adequada: transformações do constitucionalismo e atualização principiológica dos direitos, garantias e deveres fundamentais. Belo Horizonte: Arraes, 2013. p. 79,130.; MORAES, Alexandre. Direito constitucional. 30. ed. São Paulo: Atlas, 2014. p. 289.

46 OLIVEIRA, Edson Rodrigues. A competência constitucional do Corpo de Bombeiros Militar para atuação na proteção ambiental. 2017. Dissertação (Mestrado em Direito) - Escola Superior Dom Helder Câmara, Belo Horizonte, 2017. p. 62. Disponível em: http://www. domhelder.edu.br/mestrado/editor/assets/arquivos_dissertacoesd efendidas/890a58fa5dbb6d35e38619b40dd232c8.pdf. Acesso em: 4 maio 2019.
}

FIGURA 5 - Círculo de interseção da Segurança Pública e Direito Ambiental

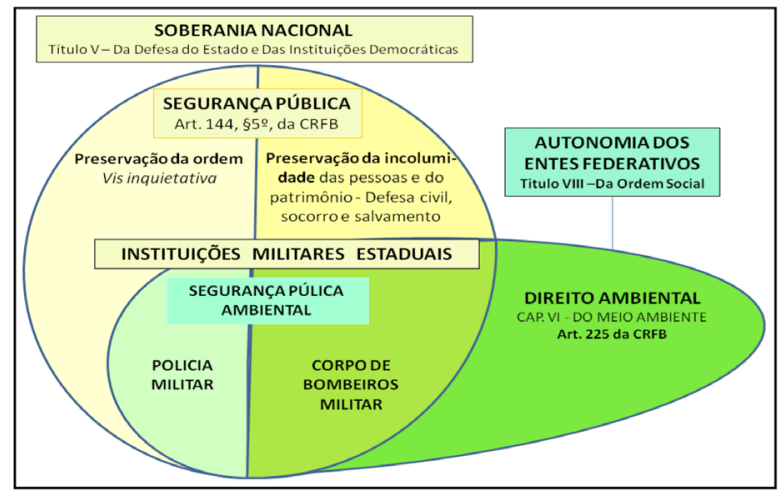

Fonte: Oliveira (2017, p. 62).

Diante da abordagem conceitual, metodológica e das premissas estabelecidas, o Estado, responsável pelo bem-estar social, deve envidar estudos e esforços para diagnosticar os problemas sazonais e outros, que, nas esferas geológica, hidrológica, climática, da saúde humana, e de outros ramos, possam consolidar previsões de desastres, planejando oportunos meios de mitigação dos efeitos. Marcelino et. al. defendem o mapeamento da potencial área de risco ${ }^{47}$. Herbert e Matthews argumentam que os métodos e técnicas de mapeamento consistem na elaboração de banco de dados e no concernente inventário socioambiental, que são essenciais e eficazes ao diagnóstico e mensuração potencial dos desastres, por conseguinte, balizando a relação risco, perigo e vulnerabilidade ${ }^{48}$.

Segundo Marcelino et. al., esse mapeamento, inventário, planejamento e regulação, viabilizam também o diálogo entre o poder público e a comunidade, especialmente pelo nexo do risco, perigo e a relação de vulnerabilidade $^{49}$. Nessa sintonia, as medidas preventivas são essenciais e implicam medidas estruturais de sistema de alerta, mapeamento das áreas de risco, conscientização

47 MARCELINO, E. V., NUNES, L. H., KOBIYAMA, M. Mapeamento de risco de desastres naturais do estado de Santa Catarina. Caminhos da Geografia (UFU), Uberlândia, v. 7, n. 17, p. 72-84, 2006. Disponível em: http://www.seer.ufu.br/index.php/caminhosdegeografia/article/download/15273/8574. Acesso em: 22 ago, 2019. 48 HERBERT, D.T.; MATTHEWS, J.A. Geography: roots and continuities. In: MATTHEWS, J. A.; HERBERT, D.T. (org.). Unifying geography: common heritage, shared future. London: Routledge, 2004. p. 3-20.

49 MARCELINO, E. V., NUNES, L. H., KOBIYAMA, M. Mapeamento de risco de desastres naturais do estado de Santa Catarina. Caminhos da Geografia (UFU), Uberlândia, v. 7, n. 17, p. 72-84, 2006. Disponível em: http://www.seer.ufu.br/index.php/caminhosdegeografia/article/download/15273/8574. Acesso em: 22 ago. 2019. 
do público-alvo e treinamento dos atores. Goerl e Kobiyama, propõem um modelo prático, simples e exequível à consecução do atinente relatório de descrição do risco, no plano da previsibilidade e antecipação aos potenciais riscos e perigos, propondo-se as medidas mitigadoras oportunas ${ }^{50}$. Assim, delinearam:

Figura 6- Papel do [Estado] no gerenciamento de desastres naturais

\begin{tabular}{|c|c|}
\hline Fases & Atividades \\
\hline Pre-evento & $\begin{array}{l}\text { mapeamento de perigo, vulnerabilidade e risco; } \\
\text { implementação de Sistema de Alerta; } \\
\text { monitoramento; } \\
\text { simulação de cenários (modelagem); } \\
\text { banco de dados de desastres; } \\
\text { banco de dados de variáveis ambientais e } \\
\text { socioeconômicas que subsidiem o mapeamento de } \\
\text { risco; } \\
\text { fiscalização de áreas de perigo e risco; } \\
\text { pesquisa científica para subsidiar medidas estruturais } \\
\text { e não estruturais; } \\
\text { integração de equipes multidisciplinares de análise } \\
\text { de risco; } \\
\text { educação ambiental; } \\
\text { educação escolar sobre ações de prevenção; } \\
\text { elaboração de materiais didáticos e informativos. }\end{array}$ \\
\hline Evento & $\begin{array}{l}\text { divulgar informações corretas sobre o evento; } \\
\text { realizar levantamento preliminar de danos; } \\
\text { participar de ações emergenciais; } \\
\text { monitoramento in loco da evolução do desastre } \\
\text { quando necessário. }\end{array}$ \\
\hline Pós-evento & $\begin{array}{l}\text { realizar levantamento oficial de danos; } \\
\text { identificar as características das pessoas atingidas; } \\
\text { identificar os condicionantes que deflagraram o } \\
\text { desastre; } \\
\text { analisar dados ambientais (chuva, vazão etc.); } \\
\text { mapear a área atingida; } \\
\text { revisar o plano diretor da área atingida; revisar os } \\
\text { mapas de perigo; vulnerabilidade e risco e atualizá- } \\
\text { los se necessário; } \\
\text { colaborar com projetos de reconstrução; } \\
\text { implementar novas redes de monitoramento e alerta } \\
\text { se necessário. }\end{array}$ \\
\hline
\end{tabular}

Fonte: Breve adaptação de Goerl e Kobiyama, 2013.

Diante da abreve amostragem bibliográfica, deduz-se a existência de vasto acervo zetético, fazendo a elação das racionais, científicas e essenciais atividades preventivas, para se evitar os onerosos efeitos dos desastres. Contudo, na prática, depreendem-se, somente os Países desenvolvidos têm aplicado a sublimidade desse legado.

\footnotetext{
50 GOERL, Roberto Fabris; KOBIYAMA, Masato. Redução dos desastres naturais: desafio dos geógrafos. Ambiência, Guarapuava (PR), v. 9, n. 1, p. 145 - 172, jan./abr. 2013. p. 164. Disponível em: https://revistas.unicentro.br/index.php/ambiencia/article/ view/1935/1934. Acesso em: 20 jun. 2019.
}

\section{Amostras de desastres naturais nos últimos anos}

São vários os episódios de catástrofes globais, vinculando questões sísmicas, climáticas e artificiais. Em todas os casos, é possível lançar a malha da gestão de riscos para mensurar e balizar o nível de vulnerabilidade das pessoas e do patrimônio, bem como o nível de eficiência, eficácia e efetividade na prestação do aporte preventivo.

No tocante aos riscos naturais ou geoclimáticos mundiais, quinze países, não necessariamente subdesenvolvidos ou desprestigiados economicamente, figuram com maiores percentuais de risco, bem como os mais confortáveis, classificando-se o Brasil em posição razoável (posição 123, com percentual de risco de 4,26), contudo, faz-se vulnerável aos eventos artificiais, como as barragens de rejeitos das mineradoras ${ }^{51}$. A revista WorldRiskIndex 2013 demonstra o seguinte elenco, mediante adaptações dos autores ${ }^{52}$ :

Figura 7 - Classificação dos países segundo o percentual de risco

\begin{tabular}{|clc|}
\hline \multicolumn{3}{|c|}{ WorldRisklndeX } \\
\hline Rank & Country & Risk (\%) \\
\hline 1. & Vanuatu & 36.43 \\
\hline 2. & Tonga & 28.23 \\
\hline 3. & Philippines & 27.52 \\
\hline 4. & Guatemala & 20.88 \\
\hline 5. & Bangladesh & 19.81 \\
\hline 6. & Solomons & 18.11 \\
\hline 7. & Costa Rica & 16.94 \\
\hline 8. & Cambodia & 16.90 \\
\hline 9. & El Salvador & 16.85 \\
\hline 10. & Timor-Leste & 16.37 \\
\hline 11. & Papua-New Guinea & 15.90 \\
\hline 12. & Brunei Darussalam & 15.80 \\
\hline 13. & Mauritius & 15.18 \\
\hline 14. & Nicaragua & 14.89 \\
\hline 15. & Japan & 14.10 \\
\hline
\end{tabular}

51 MARTÍNEZ-ALIER, Joan. El ecologismo de los pobres: conflictos ambientales y lenguajes de valoración. 5. ed. Barcelona: Icaria, 2011. 52 MUCKE, Peter. Assessing risk, reducing vulnerability. In: WORLDRISKREPORT 2013. Lars jeschonnek e mediacompany, Bonn, 2013. p. 9. Disponível em: https://collections.unu.edu/eserv/ UNU:2018/WorldRiskReport_2013_online_01.pdf. Acesso em: 10 jul. 2019.; MUCKE, Peter; SCHMITZ, Peter. What's missing: political determination and consistent implementation. In: WORLDRISKREPORT 2013. Lars Jeschonnek e MediaCompany, Bonn, 2013. p. 63. Disponível em: https://collections.unu.edu/eserv/ UNU:2018/WorldRiskReport_2013_online_01.pdf. Acesso em: 10 jul. 2019. 


\begin{tabular}{|clc|}
\hline 123. & Brazil & \multicolumn{1}{c|}{4.26} \\
\hline 146. & Germany & 3.24 \\
\hline$\ldots \ldots \ldots \ldots \ldots \ldots \ldots \ldots \ldots \ldots \ldots \ldots \ldots \ldots \ldots \ldots \ldots \ldots \ldots \ldots$ \\
\hline 159. & Singapore & 2.49 \\
\hline 160. & Israel & 2.49 \\
\hline 161. & Norway & 2.35 \\
\hline 162. & Egypt & 2.34 \\
\hline 163. & Finland & 2.28 \\
\hline 164. & Sweden & 2.26 \\
\hline 165. & United Arab Emirates & 2.10 \\
\hline 166. & Bahrain & 1.81 \\
\hline 167. & Kiribati & 1.78 \\
\hline 168. & Iceland & 1.55 \\
\hline 169. & Grenada & 1.44 \\
\hline 170. & Saudi Arabia & 1.32 \\
\hline 171. & Barbados & 1.16 \\
\hline 172. & Malta & 0.61 \\
\hline 173. & Qatar & 0.10 \\
\hline
\end{tabular}

Fonte: recortes adaptados pelos autores (WORLDRISKREPORT, 2013, p. 9, 63)

Em repertório de ilustração fática, diversos fenômenos naturais ou artificiais marcaram o século XXI, em conformidade com o mapeamento da revista WorldRiskIndex 2013. Dentre os diversos exemplos típicos de vulnerabilidade ao risco e situações de perigo de desastres, delineados pela sazonalidade e outros, ocorreram eventos concretos inquestionáveis. A vulnerabilidade destacada pela temática da justiça ambiental e espacial e do IDH também se coincidem ${ }^{53}$. A marginalização da pobreza, a falta de infraestrutura e de saneamento básico, dentre outros, consagram os resultados. O referencial teórico em evidência é de suma importância à gestão de risco pelos Estados, bem como pelas organizações que prestam ajudas humanitárias. Se há o mapeamento e inventário das questões de vulnerabilidade, sazonalidade e outros, preventivamente, numa avaliação matemática, os investimentos, por exemplo, em abrigos resistentes até à passagem das intempéries, podem ser menos onerosos que as ações reativas posteriores (com mobilização de mão de obra humana, recursos logísticos, profissionais especializados, gastos com vestuários, medicamentos, dentre outros).

Essa proposição, depreende-se, faz-se reflexiva nas amostras concretas desses eventos ${ }^{54}$, todos oportuna-

\footnotetext{
53 UNITED NATIONS DEVELOPMENT PROGRAMME. Human Development Indices and Indicators 2018. UNDP, $29 \mathrm{Fev}$. 2019, Disponível em: http://www.br.undp.org/content/brazil/pt/ home/library/idh/relatorios-de-desenvolvimento-humano/relatorio-do-desenvolvimento-humano-2018.html. Acesso em: 26 jul. 2019.

54 DÁGIOS, Giovanna. Relembre 13 desastres naturais ocorridos no século 21. UOL, São Paulo, 1 nov. 2017. Disponível em: https:/ / www.bol.uol.com.br/unibol/espm/relembre-13-desastres-naturais-
}

mente previsíveis, todavia sem a devida antecipação preventiva. Dágios registrou as treze catástrofes de maiores repercussões no lapso de 2004 à 2016, assim elencando: a) tsunami na Indonésia (magnitude 9,1) atingindo 13 países (apx. 37.000 mortos e 226.306 feridos; b) furacão Katrina, 29 ago. 2005, categoria cinco, na escala Saffir-Simpson, 1.800 vítimas; c) terremoto no Paquistão, out. 2005, Paquistão e Índia, 7,6 na escala Richter o mais forte dos últimos 100 anos, com a morte de 75 mil pessoas, quase dois milhões de desabrigados; d) Ciclone em Mianmar, 2008, ciclone Nargis, onda enorme que matou quase 80.000, 1 milhão de desaparecidos; e) terremoto no Chile, 2010, terremoto de 8,8 graus e um tsunami com ondas de até 300 metros, mais de 800 mortos, 800 mil desabrigados e prejuízo de cerca de 30 bilhões de dólares; f) terremoto no Haiti, país mais pobre da América, mais de 60\% da população subnutrida e em extrema miséria. Em janeiro de 2010, sofreu outro terremoto de magnitude 7, matando 200 mil pessoas e deixando milhões de desabrigados; g) desabamento no Rio de Janeiro, 12 de janeiro 2011, milhões de metros cúbicos de água e lama desceram pelas encostas da região a uma velocidade $150 \mathrm{~km} / \mathrm{h}$, resultando em mais de 900 mortos e 30 mil desabrigados; h) tsunami no Japão, março de 2011, tremor de 8.9 de magnitude, e um tsunami, com ondas de até 10 metros de altura, 15.000 mortos, 17.000 desaparecidos e 18.000 casas destruídas; i) tufão Hayian nas Filipinas, nov. 2013, ultrapassou 300 $\mathrm{km} / \mathrm{h}$, categoria 5 , aproximadamente 10.000 mortos; j) terremoto na Itália, ago. 2016, magnitude 6,2, 299 mortos, 7.500 italianos desabrigados; k) furacão Harvey, 2017, matou 44 pessoas e afastou de suas casas quase 1 milhão de norte-americanos, provocando prejuízos na ordem de US\$ 160 bilhões; 1) furacão Irma, início de set. 2017, no Sudeste dos EUA, categoria 4. No país, 134 mortos, 1,5 milhão de imóveis comerciais e residenciais sem energia; m) terremotos no México, 19 set. 2017, 361 mortos, vitimou 10 mil pessoas, escala 7,1.

A assertiva da gestão de riscos propõe que, diante desses eventos, as pessoas com oportunidades de "abrigo adequado" (pelos artefatos de engenharia acessíveis), potencialmente subsistirão, enquanto outras mais vulneráveis serão atingidas pelos efeitos traumáticos. Em breve analogia, os países melhores estruturados, a exemplo do Japão e relação com os fenômenos sísmicos, com tecnologias avançada para construção civil,

ocorridos-no-seculo-21.htm. Acesso em: 29 abr. 2019. 
detêm capacidade de resposta, todavia, outros países em eventos de magnitudes similares não obterão êxito em eventos de próximas escalas.

No contexto geológico, diversos fenômenos sísmicos de proporções catastróficas ocorreram recentemente. No ano de 2018, aconteceram vários terremotos com efeitos devastadores, conforme a Agência $\mathrm{EFE}^{55}$. Nessa tônica, foram evidenciados diversos registros e respectivos graus na escala Richter: n) 6 de fevereiro, Taiwan (6,4), com epicentro 18,3 quilômetros ao norte da cidade de Hualien, e deixa 17 mortos e 278 feridos; o) 16 de fevereiro $(7,2)$ com epicentro no estado mexicano de Oaxaca também sacode a Cidade do México, o centro e o sul do país, causando 14 mortes e danos em cerca de mil residências; p) 26 de fevereiro $(7,5), 145$ pessoas morrem e 300 ficam feridas nas montanhas do interior de Papua Nova Guiné; q) 5 de agosto $(6,9)$, indonésia de Lombok, com réplicas de (6,3 e 6,9), causa pelo menos 557 mortes, tornando necessário o deslocamento de quase 400 mil pessoas e 7 mil turistas das ilhas Air, Meno e Trawangan; r) 5 de setembro $(6,7)$, ilha de Hokkaido, no Japão, e causa deslizamentos de terra que matam 44 pessoas, a maioria na cidade de Atsuma; s) 28 de setembro $(7,5)$ tsunami, norte da ilha indonésia de Celebes, Palu e Donggala, deixa 2.256 mortos, cerca de 1,3 mil desaparecidos, mais de 200 mil deslocados e milhares de edifícios danificados; t) 6 de outubro $(5,9)$ graus, norte do Haiti, com epicentro a 20 quilômetros de Port-de-Paix, e deixa, pelo menos, 15 mortos, mais de 300 feridos e sete mil casas destruídas.

No decurso do mesmo ano, segundo a mesma agência de informação, outras calamidades ocorreram, registrando-se severos prejuízos à humanidade e ao meio ambiente (complexos bióticos e abióticos dilacerados). Nessa ótica, o editorial em epígrafe categorizou os eventos principais, tais como os incêndios, furações, tufões e ciclones, e ondas de frios. No que atine aos incêndios florestais, milhares de hectares (ha) de áreas cobertas com vegetação e outros bens foram queimadas, respectivamente por área, local e lapso temporal, tais como: 5.945ha - Nicarágua, 3 a 13 de abril; 43.724ha - Spring Creek, Colorado (EUA), 27 de junho a julho; 1500ha (94 pessoas mortas, 180 feridos) - Mati, na

\footnotetext{
55 RETROSPECTIVA 2018: catástrofes: principais catástrofes naturais no mundo em 2018. Agência EFE, Madrid [Espanha], 20 dez. 2018. Disponível em: https://www.efe.com/efe/brasil/varios/principais-catastrofes-naturais-no-mundo-em-2018/50000250-3848041. Acesso em: 29 abr. 2019
}

região de Atica, na Grécia, 23 e 24 de julho; 93000ha (mais de mil edifícios queimados e 8 mortes) - Redding, na Califórnia. em 23 de julho a 30 de agosto; 185.800ha - Califórnia, no período de 27 julho a 9 de setembro; 26.763 há - Monchique, Portugal, no interregno de 3 a 10 agosto; 92000ha - Garden Route, África do Sul, no mês de novembro; 527ha (138 eventos) - estado de Queensland, Austrália, em novembro; 62.052ha (88 mortos e 200 desaparecidos) - incêndio Camp Califórnia, em 8 de novembro; 39.233ha (matando três pessoas e destruindo propriedades de várias celebridades) - incêndio Woolsey, Los Angeles, na Califórnia, também na mesma data.

O mesmo editorial, em paradoxal inversão de temperatura, pelo desequilíbrio climático, trouxe à baila inusitadas ondas de frio. Nesse diapasão foram registrados: a) de 30 de dezembro 2017 a 7 de janeiro - onda de frio em grande parte dos Estados Unidos deixa 22 mortos, a maioria nos estados de Wisconsin e Texas; b) 2 e 8 de janeiro - pelo menos 11 pessoas, integrantes de famílias de baixa renda, morrem na região de Tarai, no Nepal, devido a uma onda de frio; c) 18 a 23 de janeiro - um grupo de 18 refugiados sírios morre pelo frio na região de Jarod Suairi, próxima à fronteira entre Síria e Líbano, país no qual tentavam entrar de maneira ilegal; d) 25 de fevereiro $-1^{\circ}$ de março - onda de frio com temperaturas de até 25 graus negativos mata 38 pessoas em países da Europa Central e do sudoeste do continente. Entre as vítimas, 21 que morreram na Hungria, oito na República Checa e as demais na Eslováquia e na Romênia; e) 26 de fevereiro a $1^{\circ}$ de março - a França registra quatro mortes devido à onda de frio siberiano que atravessou o país; f) junho - julho, região andina de Puno, no Peru, intensas nevascas e temperaturas menores de 20 graus abaixo de zero na provocam mais de cem mortes, principalmente de crianças e idosos, a maioria vítimas de pneumonia.

O primeiro semestre de 2019 também foi perpetuado de vários desastres ambientais ocorridos pelo mundo. As causas mais comuns decorrem do desenfreado desmatamento, impermeabilização do solo, produção exorbitante de GEEs, sacrifícios e assoreamento dos cursos d'água ${ }^{56}$. A falta de zelo, com os preceitos da preDisponível em: https://www.e-publicacoes.uerj.br/index.php/rdc/ 
venção, fomentam as consequentes catástrofes. Assim, laconicamente, ilustram os eventos dos países do sul da África, com elevados índices de risco ${ }^{57}$, como também diversos outros episódios, naturais ou antrópicos, que ceifaram a vida de muitas pessoas ${ }^{58}$. Ainda, no início de maio, o Ciclone Fani esteve ativo na China e na Índia ${ }^{59}$, fazendo mortes, desabrigados e prejuízos sem precedentes; no início de julho de 2019, as elevadas temperaturas na Europa já assolam a população, enquanto, na Grécia, um temporal deixa rastro de destruição ${ }^{60}$.

article/view/27045/21067. Acesso em: 5 ago. 2019.

57 INUNDAÇÕES e deslizamentos deixam 51 mortos na África do Sul: serviços meteorológicos advertiram que esta situação se manterá até quarta-feira, podendo afetar pontes e estradas das zonas. Exame, São Paulo, 24 abr. 2019. Disponível em: https://exame. abril.com.br/mundo/inundacoes-e-deslizamentos-deixam-51-mortos-na-africa-do-sul/. Acesso em: 30 abr. 2019.; CICLONE Kenneth atinge Moçambique um mês após Idai, que deixou mil mortos: Ciclone resultará, nos próximos dez dias, o dobro de chuvas das que foram originadas pelo ciclone Idai. Exame, São Paulo, 26 abr. 2019a. Disponível em: https://exame.abril.com.br/mundo/ciclonekenneth-atinge-mocambique-um-mes-apos-idai-que-deixou-milmortos/. Acesso em: 30 abr. 2019.; CICLONE Kenneth provoca enchentes e deixa mortos em Moçambique: com 200 mil habitantes, a cidade de Pemba foi atingida pelas fortes chuvas e ao menos 38 pessoas morreram. Exame, São Paulo, 29 abr. 2019b. Disponível em: https://exame.abril.com.br/mundo/ciclone-kenneth-provocaenchentes-e-deixa-mortos-em-mocambique/. Acesso em: 29 abr. 2019.

58 BETIM, Filipe. Tempestade esperada, tragédia evitável: o ciclo mortífero do Rio: dados oficiais indicam que Prefeitura do Rio vem investigando cada vez menos na prevenção de enchentes e proteção de encostas. Mortes elevam pressão sobre Crivella. El País, São Paulo, 9 abr. 2019. Disponível em: https://brasil.elpais.com/ brasil/2019/04/09/politica/1554839806_255766.html. Acesso em: 29 abr. 2019.; SABOYA, Érica; BETIM, Felipe. Temporal no Rio deixa mortos, soterra ônibus e destrói, novamente, ciclovia: ventos atingiram $110 \mathrm{~km} / \mathrm{h}$ e sirenes que alertavam moradores para deixar suas casas soaram na Rocinha. Ao menos seis pessoas morreram. El País, São Paulo, 7 fev. 2019. Disponível em: https://brasil.elpais.com/brasil/2019/02/07/politica/1549542559_653158.html. Acesso em: 30 fev. 2019.; ROSSI, Marina. Tragédia em Brumadinho: quantos erros ainda serão necessários até que a Vale aprenda? [Dez dias após o rompimento da barragem, Fiocruz alerta para doenças que podem acometer a cidade e fazer perdurar essa tragédia por meses, a exemplo de Mariana. El País, São Paulo, 5 fev. 2019. Disponível em: https://brasil.elpais.com/brasil/2019/02/05/politica/1549395601_506614.html. Acesso em: 5 fev. 2019.

59 VILLENA, Juan José; ROBLES, Tiago. Ciclone Fani: os vídeo mais impactantes: compilação dos vídeos mais virais do Ciclone Tropical Fani: a tempestade já deixa 11 mortos e milhões de evacuados em Orissa e Bangladesh: os danos são incontáveis. O tempo.com, São Paulo, 4 maio 2019. Disponível em: https://www.tempo.com/ noticias/actualidade/ciclone-fani-os-videos-mais-impactantes.html. Acesso em: 4 maio 2019.

60 ONDA de calor pode elevar temperatura a $48^{\circ} \mathrm{C}$ na Europa e quebrar recorde. BBC, São Paulo, 2 ago. 2019. Disponível em: https://www.bbc.com/portuguese/internacional-45053346. Acesso em: 3 ago. 2019
Diante dos eventos concretos catalogados e apareamento conceitual temático, é possivel deduzir a vulnerabilidade típica, em face das condições geopolíticas e climáticas. No último exemplo, do ciclone Fani ${ }^{61}$, que atingiu dois países com IDH diversos, a China em sétimo lugar e a índia na posição 130, com 42 mortes em 5 maio 2019, na classificação da UNDP, entre 189 países, com níveis de vulnerabilidades, e, portanto, antagônicos. O Diante da previsibilidade do risco e do desastre, preventivamente, o Estado deve envidar providências mitigadoras da vulnerabilidade, compensando os níveis de risco e perigo. A exemplo das baixas temperaturas e elevados índices pluviomátricos, no respectível lapso temporal de sazonalidade, caberiam medidas solidárias de construção de abrigos públicos seguros, multifuncionais (como estádios de futebol cobertos, edificações prediais escolares) e recolhimento oportuno de pessoas e animais, no que couber. As mobilizações internacionais poderiam ser mais efetivas e frutíferas se investissem na construção desses abrigos planejados. Em países desenvolvidos, como os Estados Unidos, a praxe impera o envolvimento da gorvernança, todavia, há ainda possibilidades de frustrações por diversos fatores, como tradiçoes da liberdade de escolhas pessoais e respectiva autonomia do livre arbítrio, dentre outras inerentes aos usos e costumes. Todavia, em países classificados pelo baixo IDH, potencialmente, a exemplo do Brasil, objetivamente, pelos resultados auferidos, o Estado ainda se enverada pela metodologia arcaica (enaltecimento da ameaça e pelo agir reativamente), já solapada no século XVIII (Voltaire e Rousseau), em detrimento da segurança pública das pessoas e do patrimônio.

\section{Rompimento de baragens de rejeitos em Minas Gerais}

No Brasil, dentre os desastres de maiores repercussões, destacam-se os sucessivos rompimentos das

61 INUNDAÇÕES deixam mais de 30 mortos na Indonésia: na província de Bengkulu, 29 pessoas morreram e 13 estavam desparecidas após as fortes chuvas. Exame, São Paulo, 29 abr. 2019. Disponível em: https://exame.abril.com.br/mundo/inundacoesdeixam-mais-de-30-mortos-na-indonesia/. Acesso em: 30 abr. 2019.; CICLONE Fani deixa 42 mortos na índia e em Bangladesh. Correios Brasiliense, Brasília, 5 maio 2019c. Disponível em: https:// www.correiobraziliense.com.br/app/noticia/mundo/2019/05/05/ interna_mundo, 753213 /ciclone-fani-deixa-42-mortos-na-india-eem-bangladesh.shtml. Acesso em: 10 jul. 2019. 
barragens de rejeitos de minérios em Minas Gerais. Consoante Bresser, com base em informações governamentais, das 698 barragens de rejeitos catalogadas em Minas Gerais, 22 estão com suas integridades comprometidas $^{62}$. Os três últimos eventos de rompimento de barragens ocorreram nos municípios de Miraí, Mariana e Brumadinho, todos com severos prejuízos. Os noticiários divulgaram a realidade fática e a política dos aludidos rompimentos, determinando-se a metodologia de prevenção ou de reação vigente no País.

O primeira das três barragens rompidas, denominada de São Francisco, ocorreu no dia 10 de janeiro de 2007, no município de Miraí, sob responsabilidade da mineradora Bauminas, antiga Mineração Rio Pomba Cataguases, com resíduos minerais de bauxita, atingindo o rio Muriaé, desaguando no oceano Atlântico, no Rio de Janeiro, não havendo registro de vítimas fatais, mas de danos de salubridade humana e contaminação de peixes, além de prejuízos patrimoniais, decorrentes das enchentes em áreas urbanas e áreas rurais de atividades agropecuárias ${ }^{63}$.

O segundo rompimento adveio da barragem de Fundão, ocorrido em 5 de novembro de 2015, em Mariana, sob responsabilidade da Mineração San Marco, com o derramamento aproximado de 50 milhões de metros cúbicos (dos aproximados 60 milhões estocados) de lama de rejeitos de minério de ferro e outros metais pesados $^{64}$. O percurso da lama atingiu o rio doce e alcançou o oceano Atlântico, no Espirito Santo, deixando 19 vítimas fatais, severas destruições patrimoniais e contaminações com metais pesados, mortandade de mais de

62 BRESSER, Deborah. Das 698 barragens cadastradas em MG, 22 estão sem estabilidade: Relatório da FEAM aponta classificação e riscos das estruturas que fazem parte do programa de Gestão de Barragens de Rejeitos e Resíduos. Record [R7], Belo Horizonte, 29 jan, 2019. Disponível em: https://noticias.r7.com/minas-gerais/ das-698-barragens-cadastradas-em-mg-22-estao-sem-estabilidade-26012019. Acesso em: 20 ago. 2019.

63 ANTUNES, Rafael; BRUM, Renata; OLIVEIRA, Roberta. Zona da Mata ainda se recupera de rompimento de barragem há 9 anos: solo não tem mais interferência, diz professor; rio sofre impacto. Bauminas Mineração garantiu que cumpriu o solicitado após o acidente. Globo [G1], Belo Horizonte, 7 nov. 2015. Disponível em: http://g1.globo.com/mg/zona-da-mata/noticia/2015/11/zonada-mata-ainda-se-recupera-de-rompimento-de-barragem-ha- 9 -anos. html. Acesso em: 1 ago. 2019.

64 LAMA da Samarco pode ser "bomba-relógio" de metais pesados no Rio Doce: rejeitos provenientes do desastre em Mariana (MG) continuam chegando ao estuário do Rio Doce. Jornal da USP, São Paulo, 19 jul. 2018. Disponível em: https://jornal.usp.br/ciencias/ciencias-ambientais/lama-da-samarco-pode-ser-bomba-relogio-de-metais-pesados-no-rio-doce/. Acesso em: 2 ago. 2019.
11 toneladas de peixes e anfíbios, dentre outros danos ${ }^{65}$.

O evento mais recente ocorreu em 25 de janeiro 2019, no município de Brumadinho, sob responsabilidade da Mineradora Vale, com rompimento da barragem do Córrego do Feijão, com 242 mortos identificados e 28 pessoas desaparecidas, deixando rastro de destruição em Brumadinho e municípios confrontantes com o Rio Paraopeba, com índices de contaminação até a represa de retiro baixo, no município de Felixlândia- $\mathrm{MG}^{66}$.

Os fatores análogos dos cenários desses eventos foram "previsíveis". Diante das reflexões iluministas, poderiam ser mitigadas, pois, desde a sazonalidade pluviométrica, a questão da altitude e gravidade, a formação de lâminas de acordo com o peso dos metais acumulados e da formação dos taludes das barragens, as construções à jusante e às margens das calhas dos rios, o acúmulo de material nocivo que poderia ser diluído como matéria prima sustentável, como o emprego na infraestrutura viária e na construção civil ${ }^{67}$, dentre outros.

Quanto às datas desses eventos (10 jan. 2007, 5 nov. 2015, 25 jan. 2019) e dados do Instituto Nacional de Meteorologia (INMET) ${ }^{68}$, não é estranho ao mapea-

65 HÁ 3 anos, rompimento de barragem de Mariana causou maior desastre ambiental do país e matou 19 pessoas. Globo, São Paulo, 25 jan. 2019. Disponível em: https://g1.globo.com/mg/minas-gerais/ noticia/2019/01/25/ha-3-anos-rompimento-de-barragem-de-mariana-causou-maior-desastre-ambiental-do-pais-e-matou-19-pessoas. ghtml. Acesso em: 20 ago. 2019.

66 BRUMADINHO: Sobe para 242 o número de mortos identificados em rompimento de barragem da Vale. Globo [G1], Belo Horizonte, 25 maio 2019. Disponível em: https://g1.globo.com/mg/ minas-gerais/noticia/2019/05/25/brumadinho-sobe-para-242-onumero-de-mortos-identificados-no-rompimento-de-barragem-davale.ghtml. Acesso em: 20 ago. 2019.

67 OLIVEIRA, Tales Moreira de. Caracterização de misturas de rejeitos de minério de ferro melhoras com adição de cimento com vistas à aplicação em estradas e aterros. 2013. Dissertação (Mestrado em Engenharia Civil) - Universidade Federal de Viçosa, 2013. Disponível em: https:// www.locus.ufv.br/bitstream/handle/123456789/3807/texto $\% 20$ completo.pdf? sequence=1\&isAllowed=y. Acesso em: 20 ago. 2019.; BARBOSA, Paôlla de Carvalho. Aproveitamento de rejeito da concentração de minério de ferro na produção de cerâmica vermelha. 2017. Monografia (Trabalho de Conclusão de Curso de Engenharia de Minas) - Universidade Federal de Ouro Preto, 2017. Disponível em: https:// www.monografias.ufop.br/bitstream/35400000/496/6/MONOGRAFIA_AproveitamentoRejeitoConcentra $\% \mathrm{C} 3 \% \mathrm{~A} 7 \% \mathrm{C} 3 \% \mathrm{~A} 3 \mathrm{o}$. pdf. Acesso em: 20 ago. 2019.

68 BRASIL. Instituto Nacional de Meteorologia - INMET. $5^{\circ}$ Distrito de Meteorologia - Minas Gerais. [Nota Técnica n. 004 - 2017]: estação chuvosa em Minas Gerais: variabilidade interanual observada entre as estações chuvosas de 2007/2008 a 2016/2017: Seção de Análise e Previsão do Tempo - SEPRE. Belo Horizonte, 2017. Disponível em: http://www.inmet.gov.br/portal/notas_tecnicas/2017/OUTUBRO/Nota_tecnica_CEDEC_04_17.pdf. Acesso em: 20 ago. 2019. 
mento da sazonalidade das monções (de final da primavera e verão) da região Sudeste do Brasil, uma vez que os rompimentos ocorreram em período de elevada pluviometria. Essas características justificam os ambientes úmidos e de solos encharcados dos rústicos taludes e respectiva elevação dos riscos, facilitando não somente liquefação proposta por Furtado ${ }^{69}$, mas também o descolamento e levitação das barragens, em face das lâminas dos metais pesados, que ocupam o fundo da barragem, escoados por gravidade e dispostos segundo o peso específico sob a pressão atmosférica, dinâmica das temperaturas incidentes, choque das máquinas e explosões, dentre outros, considerando ainda o peso (tonelada por metro cúbico $)^{70}$. A argila de construção da barragem, retirada do próprio ambiente, pesa cerca de 1 a 3 ton. por $\mathrm{m}^{3}$, enquanto a diversidade de metais pesados (média entre 7 a 15 ton. por $\mathrm{m}^{3}$ ) se dispõem pelo fundo da barragem, segundo a ocupação pela gravidade e peso específico dos metais (assim, por exemplo, uma coluna de 7 metros de altura do talude $\left(3 \mathrm{t} / \mathrm{m}^{3} \times 7\right)$, comporta até 21 toneladas, enquanto a média do peso da lama $\left(7 \mathrm{t} / \mathrm{m}^{3} \times 7\right)$ pode alcançar mais de 50 toneladas para a mesma altura.

\footnotetext{
69 FURTADO, André Filipe Pimentel. Avaliação da instabilidade de vertentes e processos de erosão superficial na zona de Castelo Branco, Furnas, ilha de São Miguel, Açores. 2014. Dissertação (Mestrado em Engenharia Geológica) - Faculdade de Ciências e Tecnologia, da Universidade Nova de Lisboa, 2014. p. 41-42. Disponível em: https://run. unl.pt/bitstream/10362/13955/1/Furtado_2014.pdf. Acesso em: 20 ago. 2019.

70 MUNIZ, Daphne Heloisa de Freitas; OLIVEIRA-FILHO, Eduardo Cyrino. Metais pesados provenientes de rejeitos de mineração e seus efeitos sobre a saúde e o meio ambiente. Universitas: Ciências da Saúde, v. 4, n. 1 / 2, p. 83-100, 2006 [ISSN: 1678-5398 83]. Disponível em: https://www.publicacoesacademicas.uniceub.br/cienciasaude/article/viewFile/24/40. Acesso em: 3 fev. 2019. LIMA, Verônica Ferreira; MERÇON, Fábio. Metais pesados no ensino de química. UFJF, Juiz de Fora, 27 set. 2011. Disponível em: http:/ / www.ufff.br/baccan/files/2012/11/199-CCD-7510.pdf. Acesso em: 3 fev. 2019.; LOCKE, John. Dos tratados sobre o governo. São Paulo: Martins Fontes, 1998.; PESOS específicos de materiais: materiais soltos. Prodetec, São Paulo, 2019. Disponível em: http://www.prodetec.com.br/downloads/pesos_especificos.pdf. Acesso em: 3 fev. 2019.; PETERS, Brainard Guy. O que é governança? Revista do TCU, Brasília, n. 127, maio/ago. 2013. Disponível em: https://revista.tcu. gov.br/ojs/index.php/RTCU/article/view/87/85. Acesso em: 20 jun. 2019.
}

Figura 8- Fatores de contribuição do rompimento da barragem do Córrego do Feijão

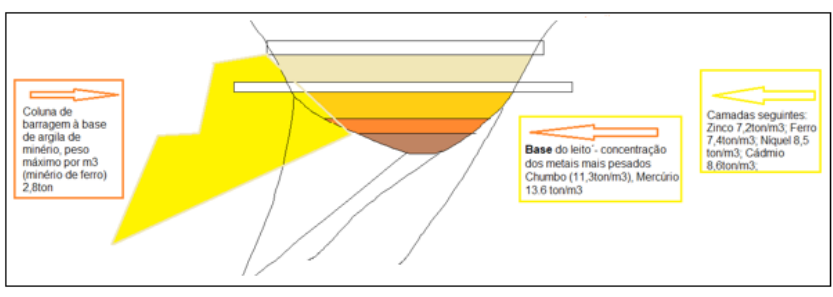

Fonte: Desenvolvido pelos autores, com fulcro em (MUNIZ; OLIVEIRA-FILHO, 2006; LIMA E MERÇON, 2011; PESO, 2019).

Nessa conjuntura, justifica-se o rompimento iniciado pela base do talude, além das pessoas e máquinas que continuaram se deslocando sobre a ilha de "terra firme" do talude, que foi tragada pela colossal quantidade de lama armazenada. Assim, a levitação pode ser atestada ainda pelas imagens do rompimento da barragem do córrego do feijão, conforme o destaque pelo retângulo amarelo, indicando o rompimento inicial pela base do talude, conforme demonstrado no vídeo do evento, divulgado por jornais televisivos da TV Globo ${ }^{71}$, ipsis:

Figura 9- Primeiro estágio de deformação que precede o rompimento pela vertente do leito

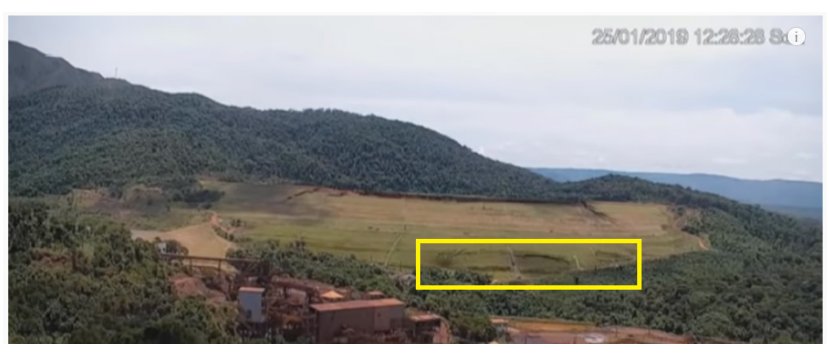

Fonte: Imagem recortada de vídeo em tempo real, adaptada pelos autores (MOMENTO, 2019).

Figura 10- Segundo estágio rompimento pela base e descolamento da vertente do talude

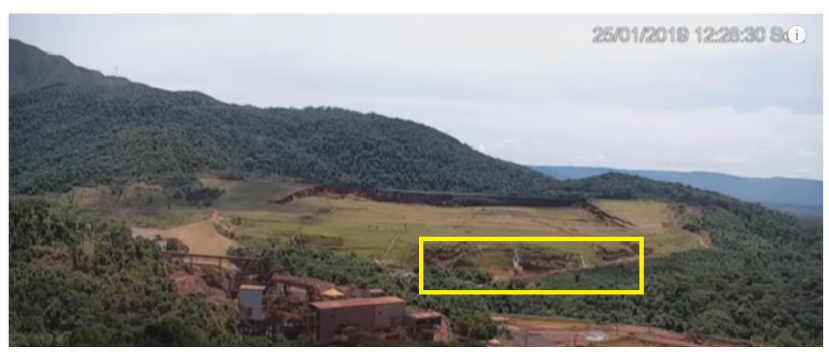

Fonte: Imagem recortada de vídeo em tempo real, adaptada pelos autores (MOMENTO, 2019).

71 MOMENTO exato do rompimento da barragem em Brumadinho
(Imagens: TV Globo). Globo, 1 fev. 2019. Disponível em: https://www.
youtube.com/watch?v=9dvTZPwgYVQ. Acesso em: 20 ago. 2019. 
Figura 11- Terceiro estágio descolamento, levitação e rompimento eq bqrragem

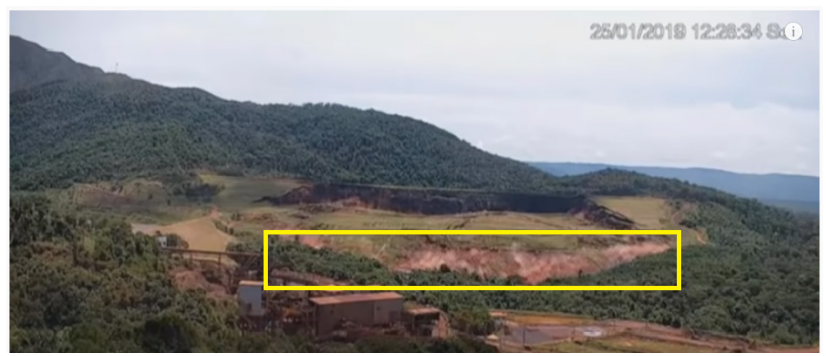

Fonte: Imagem recortada de vídeo em tempo real, adaptada pelos autores (MOMENTO, 2019).

Outro fator previsível reflete a questão da altitude e gravidade, pelo declive e calhas de escoamento da colossal quantidade de lama de rejeitos. As barragens estavam à montante e as comunidades, pessoas, animais e patrimônios vulneráveis estavam à jusante. Nesse diapasão, vislumbra-se a relevância da altitude na celeridade da condução da lama ao oceano, deixando seu rastro de destruição e contaminação, como alude Silvério na ilustração da semelhante rota de rio asiático ${ }^{72}$ :

\section{PERFIL DA ROTA CENTRAL}

A água transferida pela Rota Central chega até Beijing praticamente apenas por gravidade, sendo a travessia do rio Amarelo o grande desafio geológico do curso.

Figura 12- Percurso fluvial por gravidade

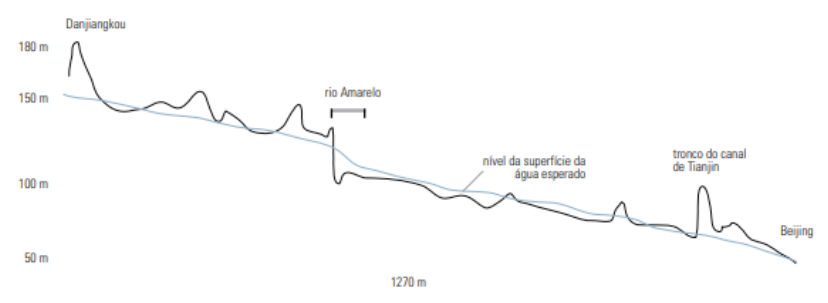

Fonte: Silvério (2012, p, 46)

Essas breves condições e situações reais são insofismáveis. À lógica de Rousseau ${ }^{73}$ e Voltaire ${ }^{74}$ proclama

\footnotetext{
72 SILVÉRIO, Mariana Strassacapa. Projeto Três Gargantas: cidade e território na China. 2012. Monografia (Graduação e Arquitetura e Urbanismo) - Faculdade de Arquitetura e Urbaanismo da Universidade de São Paulo, São Paulo, 2012. p. 42. Disponível em: http:// www.metropolefluvial.fau.usp.br/downloads/projetos/GMF_ensino-tfg_strassacarpa.pdf. Acesso em: 5 jun. 2019.

73 ROUSSEAU, Jean-Jacques. Carta de Roussean a Voltaire sobre a providência. Tradução e aparato crítico de Maria das Graças de Souza. In: MENEZES, Edmilson (org.). História e providência: Bossuet, Vico e Rousseau. Ilhéus: Editus, 2006.

${ }^{74}$ AROUET, François-Marie [pseudônimo - Voltaire]. Poemes sur le
}

reflexões seguidas de respostas dedutivas, tais como: 1) se todos os rompimentos foram precedidos de perceptíveis sinais visuais, qual(is) o representante(s) estatal(is) está(ão) fiscalizando? 2) quais foram os boletins afetos emanados pela empresa mineradora às comunidades vulnerável e aos órgãos estatais competentes? 3) se o período de maior risco, a exemplo do encharco da argila (liquefação e levitação do talude), é o chuvoso, por que não há registro de treinamentos e instruções às comunidades à jusante ou mesmo fiscalizações que antecedam essa sazonalidade? 4) se o derramamento ocorre por gravidade, por que as empresas não desenvolveram mecanismos de direcionamento e diluição gradativa da lama (exemplo de "costelas painéis de escada") ou mesmo barragens de captação à jusante? 5) se a física e outros ramos podem contribuir com a separação e retirada dos metais por gravidade e peso específico, por que não há desenvolvimento de mecanismos específicos? 6) se já existem vários estudos para uso econômico e sustentável da lama, quais a medidas incentivadas pelo Governo e praticadas pelas empresas? 7) se essas situações sugeridas são previsíveis, quais as medidas diagnósticas e operacionais preventivas adotadas (mapeamento, inventário, plano e regulação)? E outras.

\section{A fiscalização e a execução de Defesa Civil}

A execução das atividades de defesa civil no Brasil é de competência constitucional dos Corpos de Bombeiros Militares (CBM), por força do art. 144, caput e $\$ 5^{\circ}$ da $\mathrm{CRFB}^{75}$. A falta de fiscalização ${ }^{76}$ das atividades operacionais de Defesa Civil (CBM) e a falta de conhecimento dos órgãos de controle prejudicam a eficiência da prestação da segurança pública pelos órgãos compe-

désastre de Lisbonne at sur la loi naturalle, avec des prefates des notes, [...]. Paris: Galica, 1756. Disponível em: https://gallica.bnf.fr/ark:/12148/ bpt6k5727289v/f9.image. Acesso em: 25 jul. 2019.

75 BRASIL. [Constituição (1988)]. Constituição da República Federativa do Brasil de 1988. Brasília, DF: Presidência da República, [2018]. Disponível em: http://www.planalto.gov.br/ccivil_03/Constituicao/Constituição.htm. Acesso em: 1 jun. 2019.

76 BRASIL. Presidência da República. Lei n ${ }^{\circ} 12.846$, de 1 de agosto de 2013. Dispõe sobre a responsabilização administrativa e civil de pessoas jurídicas pela prática de atos contra a administração pública, nacional ou estrangeira, e dá outras providências. Diário Oficial da União, Brasília, 2 ago. 2013. Disponível em: http://www.planalto. gov.br/ccivil_03/_ato2011-2014/2013/lei/112846.htm. Acesso em: 10 mar. 2019. 
tentes e confundem as ações demandadas, conforme a reflexão de Piske, demonstrando que os julgados reconhecem as falhas e omissões dos entes estatais ${ }^{77}$. Todavia, conforme sintetiza Martines, com base no julgado da tragédia da boate Kiss, prevalece o entendimento de que, apesar do dever de fiscalização, o Estado não é garantidor universal e não pode ser punido por atos que não causou $^{78}$. A inércia do Estado não exime o garantidor da responsabilidade pelos danos causados, mas também não exime os seus servidores de serem responsabilizados administrativa, civil e até penalmente, pelos comportamentos desviados, em caso de participação direta no evento ${ }^{79}$, in verbis:

[...] com esse entendimento, a juíza Eloisa Helena Hernandez de Hernandez, da Comarca de Santa Maria, eximiu o município e o estado do Rio Grande do Sul de indenizarem Felipe de Souza Freitas e Joanatas Krug Castilhos, sobreviventes da tragédia na boate Kiss. Porém, a empresa Santo Entretenimentos, responsável pelo empreendimento, foi condenada a pagar $\mathrm{R} \$ 20 \mathrm{mil}$ para cada um pelo abalo psicológico causado pelo acidente.

Depreende-se que o representante do Estado, que, por ação ou omissão, demonstrar ineficiência na fiscalização ou controle, no que couber, segundo o modus operandi e nível de disponibilidade, conhecimento dos riscos e desiderato, pode ser submetidos a procedimento legal e, por conseguinte, ser responsabilizado cível, penal e administrativamente. A falta de fiscalização das situações ambientais e empreendimentos de risco de desastres eleva a vulnerabilidade e previsão de gastos e prejuízos. A falta de execução das atividades preventivas de defesa civil pelos CBM e diante do mapeamento de risco existente fomenta despreparo do Estado para novas catástrofes. Essa condição objetiva de meras rea-

PISKE, Oriana. Mariana: de quem é a responsabilidade pelo maior desastre ambiental brasileiro? Imprensa do TJDFT, Brasília, 22 fev. 2016. Disponível em: http://bdjur.tjdft.jus.br/xmlui/bitstream/handle/tjdft/32014/MARIANA $\% 20 \% 20 \mathrm{De} \% 20$ quem $\% 20 \% \mathrm{E} 9 \% 20 \mathrm{a} \% 20$ responsabilidade $\% 20$ pelo $\% 20$ maior $\% 20$ desastre $\% 20 \mathrm{am}$ biental $\% 20$ brasileiro.pdf? sequence $=1$. Acesso em: 20 jun. 2016.

78 MARTINES, Fernando. Indenização moral: Estado é isento de culpa, mas empresa é condenada por incêndio na boate Kiss. Consultor Jurídico, São Paulo, 10 set. 2015. Disponível em: http://www. conjur.com.br/2015-set-10/estado-isento-empresa-condenadaincendio-boate-kiss. Acesso em: 29 jul. 2016.

79 MARTINES, Fernando. Indenização moral: Estado é isento de culpa, mas empresa é condenada por incêndio na boate Kiss. Consultor Jurídico, São Paulo, 10 set. 2015. Disponível em: http://www. conjur.com.br/2015-set-10/estado-isento-empresa-condenadaincendio-boate-kiss. Acesso em: 29 jul. 2019. ções frustradas gera sensação de impotência e de insegurança às pessoas e aos respectivos patrimônios. A de fiscalização e das atividades de prevenção pelos CBM, na matéria de riscos de desastres reclama diligências pelos órgãos de controle interno e externo, independente das perscrutações do processo judicial, e não necessariamente para punir possíveis responsáveis administrativa e civilmente, mas para o feedback e alimentação do banco de dados científico (mapeamento e inventário) para reestruturar o planejamento preventivo e reordenação do comportamento dos gestores no concernente ofício, conforme aduz, inclusive, na disposição do " $\$ 7^{\circ}$, a lei disciplinará a organização e o funcionamento dos órgãos responsáveis pela segurança pública, de maneira a garantir a eficiência de suas atividades.", do 144 da $\mathrm{CRFB}^{80}$.

Assim, os métodos de gestão, privado ou público hodiernos, são análogos e consagram os princípios da previsibilidade e da antecipação preventiva, como fatores de mitigação de prejuízos e capitalização de vantagens. Dentre diversos mecanismos cíclicos diagnósticos de mapeamento, reconhecimento dos fatores e recursos objetivos de inferência no feedback ou inventário, planejamento adequado de efetivação das operações preventivas e reativas e regulamentação procedimental de uniformização, como aludiram Coutinho e Aquino, com base nos estudos de Campos, Godoy e Yin, existem vários arquétipos satisfatórios, tais como o Sistema de Qualidade Total - SQT (ou TQM -Total Quality Management, na derivação inglesa, ou gestão da qualidade total, ou SQG - Sistema de Gestão da Qualidade Total), com o ciclo PDCA (P- planejar; D- fazer; Cverificar e A- agir), e com as ferramentas " $5 \mathrm{~S}$ ” (SEIRI, ou senso de utilização, arrumação, organização e seleção; SEITON, ou senso de ordenação, sistematização e classificação; SEISO, ou senso de limpeza e zelo; SEIKETSU, ou senso de asseio, higiene, saúde e integridade; SHITSUKE, ou senso de autodisciplina, educação e compromisso) ${ }^{81}$. Portanto, verifica-se a disponibilidade

80 BRASIL. [Constituição (1988)]. Constituição da República Federativa do Brasil de 1988. Brasília, DF: Presidência da República, [2018]. Disponível em: http://www.planalto.gov.br/ccivil_03/Constituicao/Constituição.htm. Acesso em: 1 jun. 2019.

${ }^{81}$ COUTINHO, Fagner Melo José; AQUINO, Joás Tomaz de. Os $5 \mathrm{~S}$ como diferencial competitivo para o sistema de gestão da qualidade: estudo de caso de uma empresa de aços longos. Revista Gestão. Org, [S. 1.], v. 13, n. 2, p. 176-186, 2015. p. 178-180. Disponível em: http://www.revista.ufpe.br/gestaoorg/index.php/gestao/article/ view/738/0. Acesso em: 20 mar. 2019.; CAMPOS, V. F. TQC: controle da qualidade total, no estilo japonês. Minas Gerais: Nova Lima, 
do conhecimento, mas, simultaneamente, também a falta de aplicação, em detrimento socioambiental.

No plano federativo do Brasil, essas atividades vinculadas a desastres são típicas de Defesa Civil, que são inerentes à União, nos termos do art. 21, inciso XVIII, da Lei Maior, que preconiza: "planejar e promover a defesa permanente contra as calamidades públicas, especialmente as secas e as inundações". Conforme depreende-se do cotejo entre a Lei da Política Nacional de Proteção e Devesa Civil (PNPDEC) ${ }^{82}$, a Lei de transferências de recursos da União aos demais entes federativos $^{83}$, dispondo sobre o repasse de recursos, e o decreto de regulação do Sistema Nacional de Defesa $\mathrm{Civil}^{84}$, que define atribuições administrativas no âmbito federal, Estadual e Municipal, bem como da Lei de Licitações ${ }^{85}$,considerando até mesmo possíveis fraudes, em face da "imunidade" e chancela da situação "emergencial", contra as disposições contrárias e possíveis atos de corrupção, cabe aos órgãos de controle a mis-

2005.; GODOY, A. S. Estudo de caso qualitativo. In: GODOI, C. K.; BANDEIRA-DE-MELLO, R.; SILVA, A. B. (org.) Pesquisa qualitativa em estudos organizacionais, paradigmas, estratégias e métodos. São Paulo: Saraiva, 2006.; YIN, R. K. Estudo de caso: planejamento e métodos. Porto Alegre: Bookman, 2015.

82 BRASIL. Presidência da República. Lei no 12.608, de 10 de abril de 2012. Institui a Política Nacional de Proteção e Devesa Civil. PNPDEC; dispõe sobre o Sistema de Nacional de Proteção e Defesa Civil - CONPDEC. Diário Oficial União, Brasília, 11 abr. 2012. Disponível em: http://www.planalto.gov.br/ccivil_03/_ato20112014/2012/lei/L12698.htm. Acesso em: 20 jun. 2019.

83 BRASIL. Presidência da República. Lei no 12.340, de 1 de dezembro de 2010. Dispõe sobre as transferências de recursos da União aos órgãos e entidades dos Estados, Distrito Federal e Municípios para a execução de ações de prevenção em áreas de risco de desastres e de resposta e de recuperação em áreas atingidas por desastres e sobre o Fundo Nacional para Calamidades Públicas, Proteção e Defesa Civil; e dá outras providências. Diário Oficial da União, Brasília, 2 dez. 2010b. Disponível em: http://www.planalto.gov.br/ ccivil_03/_Ato2007-2010/2010/Lei/L12340.htm. Acesso em: 25 jun. 2019.

84 BRASIL. Presidência da República. Decreto n 7.257, de 10 de setembro de 2010. Regulamenta a Medida Provisória n. 494 de 2 de julho de 2010, para dispor sobre o Sistema Nacional de Defesa Civil - SINDEC, sobre o reconhecimento de situação de emergência e estado de calamidade pública, sobre as transferências de recursos para ações de socorro, assistência às vítimas, restabelecimento de serviços essenciais e reconstrução nas áreas atingidas por desastre, e dá outras providências. Diário Oficial da União, Brasília, 5 ago. 2010a. Disponível em: http://www.planalto.gov.br/ccivil_03/_ato20072010/2010/Decreto/D7257.htm. Acesso em: 29 maio 2019.

85 BRASIL. Presidência da República. Lei nº 8.666, de 21 de junho de 1993. Regulamenta o art. 37, inciso XXI, da Constituição Federal, institui normas para licitações e contratos da Administração Pública e dá outras providências. Diário Oficial da União, Brasília, 22 jun. 1993. Disponível em: http://www.planalto.gov.br/ccivil_03/ leis/18666cons.htm. Acesso em: 10 mar. 2019. ter fiscalização. A regulamentação, no âmbito nacional, converteu conceitos em definição, ratificando os argumentos já evidenciados, como descrevem os incisos do art. $2^{\circ}$, do Decreto regulamentador do Sistema Nacional de Defesa Civil ${ }^{86}$, ipsis:

Art. $2^{\circ}$ Para os efeitos deste Decreto, considera-se:

- defesa civil: conjunto de ações preventivas, de socorro, assistenciais e recuperativas destinadas a evitar desastres e minimizar seus impactos para a população e restabelecer a normalidade social;

- desastre: resultado de eventos adversos, naturais ou provocados pelo homem sobre um ecossistema vulnerável, causando danos humanos, materiais ou ambientais e consequentes prejuízos econômicos e sociais;

$[\ldots]$;

IX - ações de prevenção: ações destinadas a reduzir a ocorrência e a intensidade de desastres, por meio da identificação, mapeamento e monitoramento de riscos, ameaças e vulnerabilidades locais, incluindo a capacitação da sociedade em atividades de defesa civil, entre outras estabelecidas pelo Ministério da Integração Nacional. (Grifou-se).

No mesmo concerto, as atribuições de segurança pública são de responsabilidade da União, mas foram delegadas parcialmente aos estados, sendo solidárias entre esses entes, podem ser avocadas pela União, titular da responsabilidade, mas não podem ser subdelegadas aos municípios, quanto mais a autarquias ou instituições privadas, como reiterou Rocha ${ }^{87}$, fazendo remessa ao parágrafo único do art. $22 \mathrm{e}$, explicitamente, às disposições do art. 144 , caput e $\iint 5^{\circ}$ e $7^{\circ}$ da $\mathrm{CRFB}^{88}$, mormente em face do interesse estratégico da soberania nacional. Nesse diapasão aludem ainda os julgados do Supremo Tribunal Federal ${ }^{89}$ na repercussão geral das Ações Dire-

86 BRASIL. Presidência da República. Decreto n. 7.257, de 10 de setembro de 2010. Regulamenta a Medida Provisória n. 494 de 2 de julho de 2010, para dispor sobre o Sistema Nacional de Defesa Civil - SINDEC, sobre o reconhecimento de situação de emergência e estado de calamidade pública, sobre as transferências de recursos para ações de socorro, assistência às vítimas, restabelecimento de serviços essenciais e reconstrução nas áreas atingidas por desastre, e dá outras providências. Diário Oficial da União, Brasília, 5 ago. 2010a. Disponível em: http://www.planalto.gov.br/ccivil_03/_ato20072010/2010/Decreto/D7257.htm. Acesso em: 29 maio 2019.

87 ROCHA, Cármen Lúcia Antunes. República e federação no Brasil: traços constitucionais da organização política brasileira. Belo Horizonte: Del Rey, 1997. p. 243- 244, 287.

88 BRASIL. [Constituição (1988)]. Constituição da República Federativa do Brasil de 1988. Brasília, DF: Presidência da República, [2018]. Disponível em: http://www.planalto.gov.br/ccivil_03/Constituicao/Constituição.htm. Acesso em: 1 jun. 2019.

89 BRASIL. Supremo Tribunal Federal. Ação Direta de Incon- 
tas de Inconstitucionalidades n. 236, n. 1.182 e n. 2.827. Dessarte, as atividades operacionais de Defesa Civil, à elucidação de Oliveira, no teatro real de operações cabe ao braço coercitiva do Estado, com fulcro na mens legis da soberania e força especializada, os $\mathrm{CBM}^{90}$, ipsis:

A CRFB (BRASIL, 1988), no lastro da soberania, delegou às IMEs as atribuições de execução da segurança pública e, especificamente aos CBMs, a missão da preservação da incolumidade pública das pessoas e do patrimônio. A União, estranhamente, por meio de lei ordinária, reincorporou tais atribuições em desvio à volição do art. 144, SS $6^{\circ}$ e $7^{\circ}$. A Lei n. 12.608 (BRASIL, 2012a), em sentido amplo, retira a autonomia dos Estados e ainda subdelega aos Municípios as atribuições de defesa civil, considerando o seu poder financeiro de mobilização estratégica, no consórcio da Lei n. 12.340 (BRASIL, 2010b), quando caberia a mera regulação geral da atuação estadual, nos termos do art. $7^{\circ}$, contudo destacando a competência técnica e pragmática dos $\mathrm{CBMs}$, sem vincular operações táticas aos entes municipais.

Essa hipotética confusão só desassiste o público-alvo, pois desinforma a sociedade, gera solução de continuidade $^{91}$, sobreposição desnecessária de esforços, prejuízos ao erário e sobretudo permite escapes aos atores responsáveis para se safarem das responsabilidades, mormente pelas pretensas dúvidas quanto aos hipotéticos conflitos de competência, que não existem. Como explanado pelos constitucionalistas ${ }^{92}$, Oliveira e Silva,

stitucionalidade. (Plenário). ADI 1.182/DF. Relator: Min. Eros Grau. Brasília 24 de novembro 2005, Diário da Justiça (DJ), 10 mar. 2006. Disponível em: http://stf.jusbrasil.com.br/jurisprudencia/14735544/acao-direta-de-inconstitucionalidade-adi1182-df. Acesso em: 10 jun. 2016.; BRASIL. Supremo Tribunal Federal. (Plenário). Ação Direta de Inconstitucionalidade. ADI 236/RJ. Relator: Min. Octavio Gallotti, julgamento: 7 maio 1992. Diário da Justiça (DJ). 1 jun. 2001. Disponível em: http://stf.jusbrasil.com. $\mathrm{br} /$ jurisprudencia/751069/acao-direta-deinconstitucionalidade-adi236-rj. Acesso em: 12 jun. 2016.; BRASIL. Supremo Tribunal Federal. (Plenário). Ação Direta de Inconstitucionalidade. ADI 2.827/ RS. Relator: Min. Gilmar Mendes. Brasília, 16 de setembro 2010. Diário da Justiça Eletrônico, 6 abr. 2011. Disponível em: http://stf. jusbrasil.com.br/jurisprudencia/14797104/agregna-acao-diretadeinconstitucionalidade-adi-2827-rs-stf. Acesso em: 10 jun. 2016.

90 OLIVEIRA, Edson Rodrigues. A competência constitucional do Corpo de Bombeiros Militar para atuação na proteção ambiental. 2017. Dissertação (Mestrado em Direito) - Escola Superior Dom Helder Câmara, Belo Horizonte, 2017, p. 79-80. Disponível em: http://www. domhelder.edu.br/mestrado/editor/assets/arquivos_dissertacoesd efendidas/890a58fa5dbb6d35e38619b40dd232c8.pdf. Acesso em: 4 maio 2019.

91 SOLUÇÃO de continuidade. In: DICIONÁRIO priberam da língua portuguesa [em linha], 2008-2013. Disponível em: https:// dicionario.priberam.org $/$ solu $\% \mathrm{C} 3 \% \mathrm{~A} 7 \% \mathrm{C} 3 \% \mathrm{~A} 3 \mathrm{o} \% 20 \mathrm{de} \% 20 \mathrm{con}$ tinuidade. Acesso em: 20 jul. 2019.

92 OLIVEIRA, Márcio Luís de. A Constituição juridicamente adequada: pelos administrativistas ${ }^{93}$ Di Pietro e Oliveira, a sinergia funcional entre os entes federativos, poderes e órgãos estatais é essencial, pois, cada qual, com suas atribuições específicas, deve interagir construtiva e solidariamente, à eficiência da prestação estatal, como consagrou a analogia do apóstolo Paulo de Tarso ${ }^{94}$ :

19. E, se todos fossem um só membro, onde estaria o corpo? 20. Assim, pois, há muitos membros, mas um corpo. 21. E o olho não pode dizer à mão: Não tenho necessidade de ti; nem ainda a cabeça aos pés: Não tenho necessidade de vós. 22. Antes, os membros do corpo que parecem ser os mais fracos são necessários; 23. E os que reputamos serem menos honrosos no corpo, a esses honramos muito mais; e aos que em nós são menos decorosos damos muito mais honra. 24. Porque os que em nós são mais nobres não têm necessidade disso, mas Deus assim formou o corpo, dando muito mais honra ao que tinha falta dela; 25. Para que não haja divisão no corpo, mas antes tenham os membros igual cuidado uns dos outros. 26.De maneira que, se um membro padece, todos os membros padecem com ele; e, se um membro é honrado, todos os membros se regozijam com ele.

A responsabilidade pela administração de recursos de defesa civil confere à União, estados e municípios, no que couber, segundo a fonte e distribuição. Já a responsabilidade pela execução de defesa civil é constitucionalmente cabível aos CBM. Entretanto, no cenário de calamidade, verificam-se disputas políticas acirradas pelos "microfones midiáticos, não raras às vezes, para apologias de falso altruísmo", como externaram Voltaire ${ }^{95}$ e Rousseau ${ }^{96}$, em repulsa à ausência das oportunas atividades "preven-

transformações do constitucionalismo e atualização principiológica dos direitos, garantias e deveres fundamentais. Belo Horizonte: Arraes, 2013. p. 210-215.; SILVA, José Afonso da. Curso de direito constitucional positivo. 37. ed. São Paulo: Malheiros, 2013. p. 46, 481.

93 DI PIETRO, Maria Sylvia Zanella. Direito administrativo. 27. ed. São Paulo: Atlas, 2014. p. 592- 593, 605.; OLIVEIRA, Edson Rodrigues. A competência constitucional do Corpo de Bombeiros Militar para atuação na proteção ambiental. 2017. Dissertação (Mestrado em Direito) - Escola Superior Dom Helder Câmara, Belo Horizonte, 2017. p. 74, 113. Disponível em: http://www.domhelder.edu.br/mestrado/ editor/assets/arquivos_dissertacoesdefendidas/890a58fa5dbb6d35 e38619b40dd232c8.pdf. Acesso em: 4 maio 2019

94 BÍBliA SAgRADA. N. T. 1 Coríntios. Tradução de Almeida, corrigida e fiel, 1994. Cap. 12. Disponível em: http://www.bibliaonline.com.br/. Acesso em: 5 jun. 2008.

95 AROUET, François-Marie [pseudônimo - Voltaire]. Poemes sur le désastre de Lisbonne at sur la loi naturalle, avec des prefates des notes, [...]. Paris: Galica, 1756. Disponível em: https://gallica.bnf.fr/ark:/12148/ bpt6k5727289v/f9.image. Acesso em: 25 jul. 2019

96 ROUSSEAU, Jean-Jacques. Carta de Roussean a Voltaire sobre a providência. Tradução e aparato crítico de Maria das Graças de Souza. In: MENEZES, Edmilson (org.). História e providência: Bossuet, Vico e Rousseau. Ilhéus: Editus, 2006. 
tivas" e decorrentes resultados efetivos ${ }^{97}$. A partir dos princípios da previsibilidade de determinada situação de risco e adoção dos mecanismos preventivos de mitigação das vulnerabilidades, por óbvio a possibilidade de estimativa de racionalização gastos e investimentos. Nos episódios evidenciados, nos países pobres e no Brasil, à ilustração concreta do rompimento de barragens, os resultados são uniformes, mas pejorativos. Percebe-se a temerosidade dos exacerbados prejuízos socioambientais e dos remanejamentos financeiros infrutíferos pelos cofres públicos (sem necessidade de comprovações, pela chancela da situação de emergência e outros), em ações meramente reativas de resgate de cadáveres.

À inferência de interpretação constitucional desonesta, especialmente por interesses políticos escusos, na busca suspeita de repasses dessas verbas emergenciais, reitera-se, sem a obrigação de prestação de contas, suplica o meticuloso tirocínio dos profissionais dos órgãos de controle. Diante das tecnologias disponíveis na atualidade, cumprem aos órgãos de controle, a fiscalização das contas e do cumprimento da missão constitucional. O povo, e em especial as comunidades vulneráveis, são sujeitos de direito legitimados a provocarem os órgãos de controle. Os órgãos de controle externos devem exigir os trabalhos preventivos e fiscalizar a execução, denunciando os desvios de condutas aflorados. Os órgãos de controle interno devem fiscalizar a eficiência, eficácia e efetividade da prestação estatal, pelo crivo dos métodos de gestão vigentes, para mitigação de gastos, racionalização da superposição de esforços e solução de continuidade, inibir a corrupção, dentre outros, para maximização da segurança das pessoas e do patrimônio e minimização da vulnerabilidade. Portanto, há necessidade de uma gestão participativa, não apenas teórica, mas envolvendo representantes do povo, do governo, da comunidade científica, de representantes do controle externo e de pessoas jurídicas vinculadas. Assim, as comunidades vulneráveis não seriam surpreendidas pelas inertes e omissas intervenções, pelos órgãos de Defesa Civil, sendo a execução, longa manus da soberania da segurança pública, atribuída aos CBM. Nesse contexto, com a devida amplitude ambiental e seus efeitos catastróficos, esclareceu Oliveira ${ }^{98}$ :

${ }_{97}$ CAMPOS-VARGAS, Milagros; APARICIO, Alejandra Toscana; ALANÍS, Juan Campos. Riesgos socionaturales: vulnerabilidad socioeconómica, justicia ambiental y justicia espacial. Cuadernos de Geografía, [S. 1.], v. 24, n. 2, p. 53-69, 2015. Disponível em: http:// www.scielo.org.co/pdf/rcdg/v24n2/v24n2a4.pdf. Acesso em: 10 jun. 2019.

98 OLIVEIRA, Edson Rodrigues. A competência constitucional do
[...] as atividades da segurança pública, na seara ambiental, geralmente são emergenciais, mas a efetividade no teatro de operações decorre de medidas e planejamentos racionais preventivos, implicando "comunicação" e colaboração mútua entre as instituições materialmente vinculadas e com os usuários, no que couber. Os órgãos ambientais devem manter comunicação dialética com os órgãos de segurança pública, e vice-versa, para maior eficiência de seus atos normativos, planejamentos e ações de proteção ambiental, por ser dever do Estado, direito e responsabilidade de todos, como ordenam os arts. 144 e 225 da CRFB (BRASIL, 1988). Nesta esfera, o exemplo do rompimento de barragens de mineradoras em Minas Gerais e outros Estados, demonstram com clarividência a dissonância comunicativa, pois os CBMs interviram reativamente aos eventos ${ }^{99}$.

Assim, como os incontestes resultados sucessivos ocorridos em Minas Gerais, nos respectivos rompimentos de barragens de rejeitos, nos municípios mineiros de Mariana e Brumadinho ${ }^{100}$, os trabalhos preventivos de fiscalização e treinamento das comunidades vulneráveis e outros deveriam ter sido implementados antes dos eventos, sob a regência do órgão de execução de Defesa Civil (CBM), e com o apoio dos demais órgãos administrativos de Defesa Civil da União, do Estado de Minas Gerais (e mesmo odo Estado secundário atingido) e dos municípios afetados, com a inclusão, também, do know-how dos órgãos ambientais. Contudo, diante do fato concreto, esta reclamada sinergia não ocorreu, em insofismáveis prejuízos socioambientais (vítimas fatais e contaminadas, exacerbado dispêndio econômico,

Corpo de Bombeiros Militar para atuação na proteção ambiental. 2017. Dissertação (Mestrado em Direito) - Escola Superior Dom Helder Câmara, Belo Horizonte, 2017. p. 63. Disponível em: http://www. domhelder.edu.br/mestrado/editor/assets/arquivos_dissertacoesd efendidas/890a58fa5dbb6d35e38619b40dd232c8.pdf. Acesso em: 4 maio 2019.

99 DELECRODE, Carla. Rompimento de barragem é problema recorrente nos Estados brasileiros: nos últimos quatro anos, cerca de oito represas racharam causando grandes prejuízos. Opinião \& Notícia, Rio de Janeiro, 23 jun. 2010. Disponível em: http://opiniaoenoticia.com.br/sem-categoria/rompimento-de-barragem-eproblema-recorrente-nos-estados-brasileiros/. Acesso em: 12 jul. 2019.; BELCHIOR, Germana Parente Neiva; SALAZAR PRIMO, Diego de Alencar. A responsabilidade civil por dano ambiental e o caso Samarco: desafios à luz do paradigma da sociedade de risco e da complexidade ambiental. RJurFA7, Fortaleza, v. 13, n. 1, p. 10-30, jan./jun. 2016. p. 5. Disponível em: http://www.fa7.edu.br/periodicos/index.php/revistajuridica/article/view/38/28. Acesso em: 20 jun. 2019.

100 PASSARINHO, Nathalia. Tragédia com barragem da Vale em Brumadinho pode ser a pior no mundo em 3 décadas. BBC News, Londres, 29 jan. 2019. Disponível em: https://www.bbc.com/portuguese/brasil-47034499. Acesso em: 25 jun. 2019. 
dentre outros, para os envolvidos e sobretudo para o Estado). Pela ótica e racionalidade dos iluministas Voltaire e Rousseau, as fotografias de cadáveres resgatados pelos bombeiros de prontidão repercutem em feedback de ineficiência, ineficácia e severo distanciamento da efetividade ${ }^{101}$. Pela sublime perspectiva dos consagrados iluministas, se o órgão de execução de defesa civil estivesse cumprido a missão constitucional, a barragem poderia até ser rompida, mas não haveriam vítimas fatais e tantos prejuízos socioambientais. Se os órgãos de controle exigissem o cumprimento da missão ao órgão de execução de defesa civil, os eventos de rompimento de barragem de rejeitos não teriam repercussão.

Atualmente, um dos grandes problemas governamentais de inferência da "pessoalidade" corresponde à temática dos "cargos e funções de confiança", que pressupõem uma "pseuda" lealdade e corporativismo à autoridade pública designante. Há um paradoxo entre os rigores do caput do art. 37 e a permissão prevista em seu inciso $\mathrm{V}$ (exceção de pessoalidade, que faculta escolhas políticas sem a prestação de concurso público para o serviço público remunerado, especialmente os cargos de cúpula). O art. 37 da CRFB preconiza, no seu caput, que "a administração pública direta e indireta de qualquer dos Poderes da União, dos Estados, do Distrito Federal e dos Municípios obedecerá aos princípios de legalidade, impessoalidade, moralidade, publicidade e eficiência e, também, ao seguinte:", e, assim, preconiza também o "S $7^{\circ}$ A lei disciplinará a organização e o funcionamento dos órgãos responsáveis pela segurança pública, de maneira a garantir a eficiência de suas atividades.", do art. 144, da CRFB ${ }^{102}$. Noutra senda, a governança, para fins de lisura e transparência na prestação constitucional da segurança pública, que abarca a execução de defesa civil, deve manter estreita observância aos princípios norteadores, cabendo a permissão da gestão participativa nos conselhos de Defesa Civil, agregando-se a representação de representantes de ór-

\footnotetext{
101 AROUET, François-Marie [pseudônimo - Voltaire]. Poemes sur le désastre de Lisbonne at sur la loi naturalle, avec des prefates des notes, [...7. Paris: Galica, 1756. Disponível em: https://gallica.bnf.fr/ark:/12148/ bpt6k5727289v/f9.image. Acesso em: 25 jul. 2019.; ROUSSEAU, Jean-Jacques. Carta de Rousseau a Voltaire sobre a providência. Tradução e aparato crítico de Maria das Graças de Souza. In: MENEZES, Edmilson (org.). História e providência: Bossuet, Vico e Rousseau. Ilhéus: Editus, 2006.

102 BRASIL. [Constituição (1988)]. Constituição da República Federativa do Brasil de 1988. Brasília, DF: Presidência da República, [2018]. Disponível em: http://www.planalto.gov.br/ccivil_03/Constituicao/Constituição.htm. Acesso em: 1 jun. 2019.
}

gãos de controle, da sociedade, da comunidade científica, dentre outros de potencial contribuição, subsidiando estudos, decisões e denunciando irregularidades, para a mister eficiência da prestação estatal e legitimidade das ações preventivas da CRFB.

Nessa senda, Oliveira ${ }^{103}$, ao descrever a constituição juridicamente adequada, preconiza que a base da organização (e do Estado) é o ser humano, dotado de acervo cultural axiológico sui generis (substrato fisiológico hereditário, emocional ou afetivo, racional ou intelectual e espiritual ou intuitivo e transexistencial, trânsito e interação consigo mesma e com os demais seres humanos em diferentes momentos, circunstâncias e papéis nos muitos mundos de seu existir). Nesse contesto regente da conduta do servidor, para prevenir atos de pessoalidade urge a explanação weberiana ${ }^{104}$ :

O funcionário autêntico — isto é, decisivo para se
julgar o regime do Reich alemão anterior a 1918 -,
de acordo com as regras de sua profissão, não deve
fazer política, mas 'administrar', e isto sobretudo de
modo imparcial; isto vale, pelo menos oficialmente,
também para os chamados funcionários
administrativos 'políticos', desde que não esteja em
jogo a 'razão de Estado', isto é, os interesses vitais
da ordem dominante. Sine ira et studio, 'sem ódio e
favor': é assim que o funcionário deve exercer seu
cargo, isto é, não deve fazer precisamente aquilo
que os políticos, tanto o líder quanto seu séquito,
têm que fazer sempre e necessariamente: lutar, pois
a parcialidade, a luta e a paixão - ira et studium -
constituem o elemento do político.

Assim, há comprometimento técnico de gestão, pois a gestão de governo pode eleger, para o ofício, pessoas não qualificadas, em detrimento do interesse público. Para balizamento dos atos dos servidores públicos (concursados, temporários ou de confiança), o "princípio da legalidade", foi evoluído ao "Princípio da Juridicidade" como destacou Chicoski, com fulcro em Romeu Felipe Bacellar Filho e dos Ministros Cármen Lúcia Antunes Rocha, Eros Roberto Grau ${ }^{105}$, verba legis: 8 fev. 2016. 
[...] a nova leitura conferida ao princípio da legalidade administrativa, qual seja, a de juridicidade, confere à atividade exercida pela Administração Pública um status que supera em muito a de "mera executora da lei”, consagrada nos primórdios do Estado de direito. Apaga-se o estigma de que a Administração representaria tão-somente um poder a ser controlado e, notadamente no cenário atual, em que lhe compete a função de prover as necessidades dos cidadãos, ressalta-se o seu papel ativo na consecução dos objetivos do Estado social e democrático de direito.

Nesse honrável paradigma urge, na visão pós-moderna da "compliance", que representa o dever dos servidores de sintonia com os atos, normas e leis, para seu efetivo cumprimento, especialmente em atos de corrupção e favorecimentos a pessoas jurídicas, conforme o norte da legislação específica ${ }^{106}$, que aglutina-se ainda a Lei de Improbidade ${ }^{107}$, que versa sobre a improbidade administrativa. $\mathrm{O}$ art. $3^{\circ}$ da Lei de Introdução às Normas do Direito Brasileiro ${ }^{108}$ preconiza, em seu, "Art. $3^{\circ}$ Ninguém se escusa de cumprir a lei, alegando que não a conhece.”. Há, ainda, o norte da Lei de procedimentos administrativos ${ }^{109}$, dentre outros códigos de ética classistas.

Nessa ideologia, em breve avaliação ao desastre na barragem de rejeitos da Vale, em Brumadinho, a temática foi discorrida, inclusive, no Seminário do Ministério Público Federal, realizado e em parceria com a Escola Superior Dom Helder Câmara, com apoio da Fundação Getúlio Vargas, em Belo Horizonte, com destaque,

\footnotetext{
106 BRASIL. Presidência da República. Lei no 12.846, de 1 de agosto de 2013. Dispõe sobre a responsabilização administrativa e civil de pessoas jurídicas pela prática de atos contra a administração pública, nacional ou estrangeira, e dá outras providências. Diário Oficial da União, Brasília, 2 ago.2013. Disponível em: http://www.planalto.gov.br/ccivil_03/_ato2011-2014/2013/lei/112846.htm. Acesso em: 10 mar. 2019.

107 BRASIL. Presidência da República. Lei no 8.429, de 2 de junho de 1992. Dispõe sobre as sanções aplicáveis aos agentes públicos nos casos de enriquecimento ilícito no exercício de mandato, cargo, emprego ou função na administração pública direta, indireta ou fundacional e dá outras providências. Diário Oficial da União, Brasília, 3 jun. 1992. Disponível em: http://www.planalto.gov.br/ccivil_03/ leis/18429.htm. Acesso em: 10 mar. 2019.

108 BRASIL. Presidência da República. Decreto-Lei no 4.657, de 4 de setembro de 1942. Lei de Introdução às normas do Direito Brasileiro. Diário Oficial da União, Rio de Janeiro, 8 out. 1942. Disponível em: http://www.planalto.gov.br/ccivil_03/decreto-lei/del4657compilado.htm. Acesso em: 30 jun. 2019.

109 BRASIL. Presidência da República. Lei no 9.784, de 29 de janeiro de 1999. Regula o processo administrativo no âmbito da Administração Pública Federal. Diário Oficial da União, Brasília, 30 jan. 1999. Disponível em: http://www.planalto.gov.br/ccivil_03/leis/ 19784.htm. Acesso em: 10 mar. 2019.
}

verbi gratia, ao tema "compliance e combate à corrupção: políticas de prevenção a desastres ambientais" com a palestra dos autores Jabur e Saboya ${ }^{110}$. A conjuntura fática, demonstrada por notícias de eventos concretos divulgadas pela imprensa hodierna, zetética (ou doutrinária) dogmática e jurisprudencial, além das insofismáveis mudanças climáticas, decorrentes das ações ou omissões antrópicas, fundamentam a quebra de paradigma, já implementada na Europa e países Anglo saxônicos desde o final do século XVIII. Não se justifica agir reativamente, sem a aplicação constitucional das medidas de "prevenção". Aqueles que perderam seus entes não serão restituídos. Os rios contaminados consumiram, além do complexo biótico e abiótico, sonhos da população adjacente, que também perderam, economicamente, a desvalorização exacerbada de seus imóveis e atividades agropecuárias e de subsistência, com elevados riscos de contaminação por metais pesados e seus efeitos.

No episódio de Brumadinho, há registro ainda de que o CBMMG tinha conhecimento do dever constitucional de ação preventiva ${ }^{111}$, conforme Ofício CBMMG/CG nº. 33/2019, e também que há indícios de interferências políticas pela influência econômica das empresas mineradoras, como demonstrou Parreiras ${ }^{112}$ ao afirmar: "documento interno havia definido que o capitão Ronaldo Rosa Lima seria transferido para Barbacena mas, após manifestações, os bombeiros esperaram 56 dias e o enviaram a Poços de Caldas.". Ainda, à combinação do pensamento de Locke à lídima regência governamental ${ }^{113}$ e dos princípios fundamentais dos hu-

110 JABBUR, Marlon; SABOYA, Felipe. Seminário: compliance e combate à corrupção: políticas de prevenção a desastres ambientais. FGV, Belo Horizonte, 23 - 24 maio 2019. Disponível em: https:// direitorio.fgv.br/eventos/compliance-e-combate-a-corrupcao-politicas-de-prevencao-a-desastres-ambientais. Acesso em 25 jun. 2019.

111 MINAS GERAIS. Corpo de Bombeiros Militar de Minas Gerais (CBMMG). Oficio CBMMG/CG ñ. 33/2019: solicitação de informações sobre tramitação da contribuição científica-jurídica do autor Edson Rodrigues de Oliveira. Belo Horizonte, 13 fev. 2019.

112 PARREIRAS, Mateus. Bombeiro que considerou barragem da CSN propensa a rompimento é transferido. Documento interno havia definido que o capitão Ronaldo Rosa Lima seria transferido para Barbacena mas, após manifestações, os bombeiros esperaram 56 dias e o enviaram a Poços de Caldas. Jornal Estado de Minas, Belo Horizonte, 5 jan. 2018. Disponível em: https://www.em.com.br/ app/noticia/gerais/2018/01/05/interna_gerais,928994/bombeiroque-considerou-barragem-da-csn-propensa-a-rompimento-e-transf. shtm. Acesso em: 28 jun. 2019.

113 LOCKE, John. Dos tratados sobre o governo. São Paulo: Martins Fontes, 1998. 
manos direitos ${ }^{114}$ defendidos por Alexy e Dworkin, além das disposições da CRFB, mormente insertas no caput e $\int 2^{\circ}$ do art. $5^{\circ}$, afirmando como cláusula pétrea que os direitos humanos, no caso o direito à vida, à segurança, à propriedade e outros, são de aplicação imediata

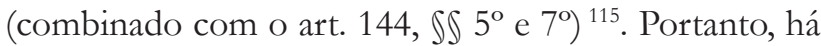
taxativa propulsão à demanda da prestação eficiente da segurança pública, que inclui a execução das atividades de defesa civil (pelos CBM) e a responsabilidade pontual das autoridades competentes para a essencial prestação estatal. Nesse concerto, cumpre aos órgãos de controle e a população, exigirem das instituições o exercício fiel da missão constitucional. Hipoteticamente, se o CBMMG possuísse o mapeado e o inventário, teriam subsídios para o planejamento e regulação da matéria e fiscalização periódica oportunas, mitigando os riscos de todas as barragens de rejeitos instaladas, treinando as comunidades vulneráveis, supervisionando o plano de contingência e a condição da integridade das barragens (visualmente é possível detectar a situação de emergência), dentre outras.

Por nexo causal, mesmo não sendo garantidor, a fiscalização e demais medidas preventivas dos órgãos administrativos e de execução de Defesa Civil e ambientais evitariam mortes de pessoas e animais e tantas perdas socioambientais, além dos onerosos dispêndios das ações reativas. Assim, diante dos riscos evidenciados e evoluídos para desastres, objetivamente, vislumbra-se que não houve efetividade nos trabalhos preventivos ${ }^{116}$ dos órgãos envolvidos. Independentemente das intervenções cabíveis aos órgãos ambientais afetos, e administrativos de defesa civil, na seara da segurança pública, especialmente no tocante às atribuições executivas ou operacionais de Defesa Civil, em sintonia ao postulado da "prevenção" centrada na "vulnerabilidade" comunitária, à dinâmica do devido mapeamento, inventário, planejamento e ordenação (em sinergia ainda com o

\footnotetext{
114 ALEXY, Robert. Constitucionalismo discursivo. Porto Alegre: Livraria dos Advogados, 2007.; DWORKIN, Ronald. O império do direito. Tradução de Jefferson Luiz Camargo. 2. ed. São Paulo: Martins Fintes, 2007.

115 BRASIL. [Constituição (1988)]. Constituição da República Federativa do Brasil de 1988. Brasília, DF: Presidência da República, [2018]. Disponível em: http://www.planalto.gov.br/ccivil_03/Constituicao/Constituição.htm. Acesso em: 1 jun. 2019.

116 BRASIL. Ministério das Cidades. Manual técnico para redução de riscos de desastres aplicado ao planejamento urbano: movimentos de massa. Gides, Brasília, dez. 2018. Disponível em: https:// www.jica.go.jp/brazil/portuguese/office/publications/c8h0vm000001w9k8-att/volume6.pdf. Acesso em: 20 jun. 2019.
}

caput e $\iint 5^{\circ}$ e $7^{\circ}$ do art. 144 da CRFB), no âmbito da Constituição do Estado de Minas Gerais ${ }^{117}$, preconizou o caput e inciso II do art. 142, verbum pro verbo:

Art. 142 - A Polícia Militar e o Corpo de Bombeiros Militar, forças públicas estaduais, são órgãos permanentes, organizados com base na hierarquia e na disciplina militares e comandados, preferencialmente, por oficial da ativa do último posto, competindo:

$[\cdots]$;

II-ao Corpo de Bombeiros Militar, a coordenação e a execução de ações de defesa civil, a PREVENÇÃo e combate a incêndio, perícias de incêndio, busca e salvamento e ESTABELECIMENTO DE NORMAS RELATIVAS À SEGURANÇA DAS PESSOAS E DE SEUS BENS CONTRA INCÊNDIO OU QUALQUER TIPO DE CATÁSTROFE; (Grifou-se)

A rejeição das instituições envolvidas ao imperativo constitucional e programático decorrente, no que couber, bem como do acervo científico existente, agravam e ampliam a extensão de vulnerabilidade das comunidades em locais de risco. Essa conjuntura situacional demonstra quão relevante e sublime os trabalhos dos órgãos de controle externo, em contemplação dos trabalhos de "compliance". A consistência do ordenamento constitucional e da contribuição científica jamais seriam condescendentes com as repercussões negativas dos acidentes em causa.

\section{Considerações finais}

Desde o trágico episódio de 1755, em Lisboa, Portugal, a comunidade europeia e anglo-saxônica, diante da temática de "risco de desastre", para fins de previsibilidade e antecipação oportuna aos efeitos prejudiciais do evento, já entendiam e solaparam a ideia de "ameaça" (potenciais traumáticos e de destruição) como elemento balizador. A partir da reflexão iluminista de Voltaire e Rousseau, houve a migração e otimização pelo apanágio da "vulnerabilidade" (falta de capacidade de resposta ou enfrentamento aos efeitos do desastre). Assim, a proposição considera o ser humano, detentor da ra-

MINAS GERAIS. [Constituição (1989)]. Constituição do Estado de Minas Gerais, de 21 de setembro de 1989. Minas Gerais: Diário do Legislativo, Belo Horizonte, 22 set. 1989. Disponível em: https://www.almg.gov.br/consulte/legislacao/completa/completanova-min.html?tipo $=\mathrm{CON} \&$ num $=1989 \& \mathrm{comp}=\& a n o=1989 \&$ text $\mathrm{o}=$ consolidado\#texto. Acesso em: 27 jun. 2019. 
cionalidade, como o responsável pela interpretação dos fenômenos naturais e artificiais, segundo a sazonalidade climática e seus intempéries, dentre outros fatores intrínsecos ou periféricos, para o oportuno mapeando, inventário, planejamento e regulação sincronizada de mitigação dos efeitos traumáticos do evento. Portanto, os procedimentos prestigiaram primariamente a prevenção, em substituição às atividades reativas durante e após o evento.

O termo "risco" (sentido amplo) se confunde com o termo "perigo" (sentido estrito), que pode ser entendido como uma fase mais avançada do risco, estando mais próxima ou já incorporado ao fenômeno ou evento, que pode ou não atingir o último nível de desastre (categorizado, em regra, por quatro níveis de magnitude - fortes chuvas e ventanias que evoluem para um ciclone, por exemplo - o último nível de desastre é também denominado de catástrofe ou calamidade). O risco é depreendido de informações catalogadas cientificamente (históricos de eventos, sazonalidade, condições análogas, a exemplo dos fatos sucessivos de rompimento das barragens de rejeitos), dependendo do nível de vulnerabilidade das pessoas e demais bens envolvidos. A prevenção, sintetizada na previsão e antecipação aos efeitos, é a máxima teleológica dos estudos de gestão do risco de desastre, sendo sine qua nom à proteção de vidas humanas, da biota e demais bens envolvidos, para mitigação da vulnerabilidade e maximizando a segurança e incolumidade pública das pessoas e do patrimônio.

O Brasil se encontra em nível confortável de risco de fenômenos naturais (classificação mundial de número 123), mas, a exemplo das barragens de rejeitos, e, em face da grande quantidade instalada (das $698 \mathrm{ca}$ talogadas em Minas Gerais, 22 estão comprometidas), pulverização regional e homogeneidade das estruturas rústicas, a base de argila e resíduos superficiais do próprio solo local, além das características geográficas predominantes da declividade e gravidade, na posição à montante, há dedutível combinação a novos desastres. Destarte, cabem aos órgãos de execução de Defesa Civil (CBM) e ambientais, a adoção efetiva dos procedimentos preventivos solidários, adequados, oportunos e de sinergia à mitigação da vulnerabilidade das pessoas e do patrimônio, em prol da prevenção contra os efeitos das catástrofes naturais e dos desastres de rompimento de barragens de rejeitos minerais.

Existem vários mecanismos cientívicos de previ- são da situação de risco e de mecanismos de preveção oportunos, na seara dos desastres. No tocante aos desastres naturais, cumpre à governança, por seus órgãos de direito, o mapeamento situacional dos elementos de vulnerabilidade e do risco, o inventário dos elementos prós e contra disponíveis, o planejamento de ações tempestivas - treinamento, remoção de pessoas e bens da área de risco, dentre outros, e a regência normativa de padornização comportamental dos envolvidos. Verbi gratia, se a situação é de pluviometria intensa, com rajadas de vento e enchentes, suscitando-se calamidade, por lógico o investimento em abrigos coletivos temporários, até a passagem do evento. Ações reativas implicam surpresa, despreparo e maximização da vulnerabilidade e multiplicação dos onerosos investimentos. Por analogia, nos casos de riscos de rompimento de barragens de rejeitos, existem múltiplos mecanismos preventivos, como a sustentável utilização dos rejeitos na construção civil, a construção de barreira de contenção gradativa da lama e possíveis desvios (canalização à juzante para outras bacias de contenção, dentre outros).

As ações reativas, sem o registro dos trabalhos preventivos realizados e sem a devida mensuração e feedback pelos órgãos de controle, implicam desídia por parte do Estado. Os investimentos em prevenção são significativamente irrisórios, em relação aos onerosos dispêndios reativos ou pós-sinistros. As vidas ceifadas e perdas materiais, além dos severos prejuízos socioambientais causados em um desastre, na assertiva de Voltaire e Rousseau, demonstram inércia e timidez nas essenciais atividades preventivas, bem como ineficiência dos órgãos envolvidos, em especial de execução de defesa civil, reitera-se, ex vi do art. 144, caput e $\int 5^{\circ}$, da CRFB e art. 142, caput e inciso II, da Constituição Estadual de Minas Gerais de 1989. Diante dos episódios demonstrados, todos poderiam maximizar os saldos positivos se a governança agisse sob o manto da racionalidade iluminista da gestão preventiva.

Os órgãos de controle têm a árdua, espinhosa, mas proporcionalmente gratificante, missão da fiscalização do cumprimento efetivo dos imperativos constitucionais e programáticos recepcionados ou decorrentes, além dos gastos realizados pelos órgãos administrativos de defesa civil, pelos instrumentos de direito cabíveis. Os Governos devem promover e fomentar a maximização da segurança pública (e ambiental), com padrões internacionais mínimos, para mitigação da vulnerabilidade humana, perante às situações de risco de desastres. A 
gestão participativa nas atividades de Defesa Civil deve ser consolidada, para maior lisura, transparência e legitimidade, especialmente nas atividades preventivas e no processo decisório. Holisticamente, tanto os órgãos de controle externo quanto dos governos devem mirar em resultados concretos de efetividade, inibindo a corrupção, com escopo no interesse público, no bem comum de todos e na sustentabilidade do meio ambiente ecologicamente equilibrado às presentes e futuras gerações.

\section{Referências}

ALEXY, Robert. Constitucionalismo discursivo. Porto Alegre: Livraria dos Advogados, 2007.

ANTUNES, Rafael; BRUM, Renata; OLIVEIRA, Roberta. Zona da Mata ainda se recupera de rompimento de barragem há 9 anos: solo não tem mais interferência, diz professor; rio sofre impacto. Bauminas Mineração garantiu que cumpriu o solicitado após o acidente. Globo [G1], Belo Horizonte, 7 nov. 2015. Disponível em: http://g1.globo.com/mg/zona-da-mata/ noticia/2015/11/zona-da-mata-ainda-se-recupera-derompimento-de-barragem-ha-9-anos.html. Acesso em: 1 ago. 2019.

AROUET, François-Marie [pseudônimo - Voltaire]. Poemes sur le désastre de Lisbonne at sur la loi naturalle, avec des prefates des notes, [...]. Paris: Galica, 1756. Disponível em: https://gallica.bnf.fr/ark:/12148/bpt6k5727289v/ f9.image. Acesso em: 25 jul. 2019

BARBOSA, Paôlla de Carvalho. Aproveitamento de rejeito da concentração de minério de ferro na produção de cerâmica vermelha. 2017. Monografia (Trabalho de Conclusão de Curso de Engenharia de Minas) - Universidade Federal de Ouro Preto, 2017. Disponível em: https://www. monografias.ufop.br/bitstream/35400000/496/6/ MONOGRAFIA_AproveitamentoRejeitoConcentra $\%$ C3\%A7\%C3\%A3o.pdf. Acesso em: 20 ago. 2019.

BECKER, Evaldo; BECKER, Michele Amorim. Contribuições de Rousseau ao entendimento dos desastres socioambientais contemporâneos. Trans/Form/ Ação, Marília, v. 37, n. 2, p. 111-126, maio/ago. 2014. Disponível em: http://www.scielo.br/pdf/trans/ v37n2/06.pdf. Acesso em: 25 jul. 2019.

BELCHIOR, Germana Parente Neiva; SALAZAR PRIMO, Diego de Alencar. A responsabilidade civil por dano ambiental e o caso Samarco: desafios à luz do paradigma da sociedade de risco e da complexida- de ambiental. RJurFA7, Fortaleza, v. 13, n. 1, p. 10-30, jan./jun. 2016. p. 5. Disponível em: http://www.fa7. edu.br/periodicos/index.php/revistajuridica/article/ view/38/2. Acesso em: 20 jun. 2019.

BERROCAL VARGAS, Milena. Análisis y evaluación de la vulnerabilidad de la población de la Fortuna de San Carlos a la actividad volcánica del volcán Arenal. 2008. Tesis (Doctorado) - Universidad de Girona, Costa Rica, San José, 2008.

BETIM, Filipe. Tempestade esperada, tragédia evitável: o ciclo mortífero do Rio: dados oficiais indicam que Prefeitura do Rio vem investigando cada vez menos na prevenção de enchentes e proteção de encostas. Mortes elevam pressão sobre Crivella. El País, São Paulo, 9 abr. 2019. Disponível em: https://brasilelpais.com/brasil/2019/04/09/politica/1554839806_255766.html. Acesso em: 29 abr. 2019.;

BÍBLIA SAGRADA. N. T. 1 Corintios. Tradução de Almeida, corrigida e fiel, 1994. Cap. 12. Disponível em: http://www.bibliaonline.com.br/. Acesso em: 5 jun. 2008.

BÖHME, Gernot; BÖHME, Hartmut. Fuego, agua, tierra, aire: una historia cultural de los elementos. Barcelona: Herder, 1996.

BRASIL. [Constituição (1988)]. Constituição da República Federativa do Brasil de 1988. Brasília, DF: Presidência da República, [2018]. Disponível em: http://www.planalto.gov.br/ccivil_03/Constituicao/Constituição.htm. Acesso em: 1 jun. 2019.

BRASIL. Instituto Nacional de Meteorologia - INMET. $5^{\circ}$ Distrito de Meteorologia - Minas Gerais. [Nota Técnica n. 004 - 2017]: estação chuvosa em Minas Gerais: variabilidade interanual observada entre as estações chuvosas de 2007/2008 a 2016/2017: Seção de Análise e Previsão do Tempo - SEPRE. Belo Horizonte, 2017. Disponível em: http://www.inmet.gov.br/portal/notas_tecnicas/2017/OUTUBRO/Nota_tecnica_CEDEC_04_17.pdf. Acesso em: 20 ago. 2019.

BRASIL. Ministério das Cidades. Manual técnico para redução de riscos de desastres aplicado ao planejamento urbano: movimentos de massa. Gides, Brasília, dez. 2018. Disponível em: https://www.jica.go.jp/brazil/ portuguese/office/publications/c8h0vm000001w9k8att/volume6.pdf. Acesso em: 20 jun. 2019.

BRASIL. Ministério do Planejamento e Orçamento. Glossário de Defesa Civil estudos de riscos e medicina 
de desastres. Imprensa Nacional, Brasília, 1998. Disponível em: http://www.defesacivil.mg.gov.br/images/documentos/Defesa\%20Civil/manuais/GLOSSARIO-Dicionario-Defesa-Civil.pdf. Acesso em: 30 jun. 2019.

BRASIL. Presidência da República. Decreto n ${ }^{\circ} 7.257$, de 10 de setembro de 2010. Regulamenta a Medida Provisória n. 494 de 2 de julho de 2010, para dispor sobre o Sistema Nacional de Defesa Civil - SINDEC, sobre o reconhecimento de situação de emergência e estado de calamidade pública, sobre as transferências de recursos para ações de socorro, assistência às vítimas, restabelecimento de serviços essenciais e reconstrução nas áreas atingidas por desastre, e dá outras providências. Diário Oficial da União, Brasília, 5 ago. 2010a. Disponível em: http://www.planalto.gov.br/ccivil_03/_ato20072010/2010/Decreto/D7257.htm. Acesso em: 29 maio 2019.

BRASIL. Presidência da República. Decreto-Lei $\mathrm{n}^{\circ}$ 4.657, de 4 de setembro de 1942. Lei de Introdução às normas do Direito Brasileiro. Diário Oficial da União, Rio de Janeiro, 8 out. 1942. Disponível em: http:/ /www.planalto.gov.br/ccivil_03/decreto-lei/del4657compilado. htm. Acesso em: 30 jun. 2019.

BRASIL. Presidência da República. Lei nº 12.340, de 1 de dezembro de 2010. Dispõe sobre as transferências de recursos da União aos órgãos e entidades dos Estados, Distrito Federal e Municípios para a execução de ações de prevenção em áreas de risco de desastres e de resposta e de recuperação em áreas atingidas por desastres e sobre o Fundo Nacional para Calamidades Públicas, Proteção e Defesa Civil; e dá outras providências. Diário Oficial da União, Brasilia, 2 dez. 2010b. Disponível em: http://www.planalto.gov.br/ccivil_03/_Ato20072010/2010/Lei/L12340.htm. Acesso em: 25 jun. 2019.

BRASIL. Presidência da República. Lei n 12.846, de 1 de afosto de 2013. Dispõe sobre a responsabilização administrativa e civil de pessoas jurídicas pela prática de atos contra a administração pública, nacional ou estrangeira, e dá outras providências. Diário Oficial da União, Brasília, 2 ago. 2013. Disponível em: http:// www.planalto.gov.br/ccivil_03/_ato2011-2014/2013/ lei/112846.htm. Acesso em: 10 mar. 2016.

BRASIL. Presidência da República. Lei nº 8.429, de 2 de junho de 1992. Dispõe sobre as sanções aplicáveis aos agentes públicos nos casos de enriquecimento ilícito no exercício de mandato, cargo, emprego ou função na administração pública direta, indireta ou fundacional e dá outras providências. Diário Oficial da União, Brasília, 3 jun. 1992. Disponível em: http://www.planalto.gov. br/ccivil_03/leis/18429.htm. Acesso em: 10 mar. 2019.

BRASIL. Presidência da República. Lei n 8.666, de 21 de junho de 1993. Regulamenta o art. 37, inciso XXI, da Constituição Federal, institui normas para licitações e contratos da Administração Pública e dá outras providências. Diário Oficial da União, Brasília, 22 jun. 1993. Disponível em: http://www.planalto.gov.br/ccivil_03/ leis/18666cons.htm. Acesso em: 10 mar. 2019.

BRASIL. Presidência da República. Lei nº 9.784, de 29 de janeiro de 1999. Regula o processo administrativo no âmbito da Administração Pública Federal. Diário Oficial da União, Brasília, 30 jan.1999. Disponível em: http:/ / www.planalto.gov.br/ccivil_03/leis/19784.htm. Acesso em: 10 mar.2019.

BRASIL. Presidência da República. Lei no 12.608, de 10 de abril de 2012. Institui a Política Nacional de Proteção e Devesa Civil. PNPDEC; dispõe sobre o Sistema de Nacional de Proteção e Defesa Civil - CONPDEC. Diário Oficial União, Brasília, 11 abr. 2012. Disponível em: http://www.planalto.gov.br/ccivil_03/_ato20112014/2012/lei/L12698.htm. Acesso em: 20 jun. 2019.

BRASIL. Supremo Tribunal Federal. (Plenário). Ação Direta de Inconstitucionalidade. ADI 1.182/DF. Relator: Min. Eros Grau, Brasília, 24 dennovembro de 2005, Plenário, Diário da Justiça (DJ), 10 mar. 2006. Disponível em: http://stf.jusbrasil.com.br/jurisprudencia/14735544/acao-direta-de-inconstitucionalidadeadi1182-df. Acesso em: 10 jun. 2016.

BRASIL. Supremo Tribunal Federal. (Plenário). Ação direta de inconstitucionalidade. ADI 236/RJ. Relator: Min. Octavio Gallotti, julgamento: 7 maio 1992. Diário da Justiça (DJ). 1 jun. 2001. Disponível em: http://stf. jusbrasil.com.br/jurisprudencia/751069/acao-diretadeinconstitucionalidade-adi-236-rj. Acesso em: 12 jun. 2016.

BRASIL. Supremo Tribunal Federal. Ação Direta de Inconstitucionalidade. ADI 2.827/RS. Rel. Min. Gilmar Mendes, julgamento: 16 set. 2010, Plenário, Diário da Justiça Eletrônico, [S. 1.], 6 abr. 2011. Disponível em: http:/ / stf.jusbrasil.com.br/jurisprudencia/14797104/agregna-acao-direta-deinconstitucionalidade-adi-2827-rsstf. Acesso em: 10 jun. 2016.

BRESSER, Deborah. Das 698 barragens cadastradas em MG, 22 estão sem estabilidade: relatório da FEAM 
aponta classificação e riscos das estruturas que fazem parte do programa de Gestão de Barragens de Rejeitos e Resíduos. Record [R7], Belo Horizonte, 29 jan, 2019. Disponível em: https://noticias.r7.com/minas-gerais/ das-698-barragens-cadastradas-em-mg-22-estao-semestabilidade-26012019. Acesso em: 20 ago. 2019.

BRILHAC, Jean-François. Le concept des cyndiniques. Paris: UVED, 2019. Disponível em: https://ressources.uved. fr/Grains_Module3/Cyndiniques/site/html/Cyndiniques/Cyndiniques.html. Acesso em: 30 jun. 2019.

BRUMADINHO: Sobe para 242 o número de mortos identificados em rompimento de barragem da Vale. Globo [G1], Belo Horizonte, 25 maio 2019. Disponível em: https://g1.globo.com/mg/minas-gerais/noticia/2019/05/25/brumadinho-sobe-para-242-o-numero-de-mortos-identificados-no-rompimento-de-barragem-da-vale.ghtml. Acesso em: 20 ago. 2019.

BULLARD, R. D. Confronting environmental racism: voices from the grassroots. Boston: South End Press, 1993.

BULLARD, R. D. Dumping in dixie: race, class, and environmental quality. Boulder, Colo.: Westview Press, 1990.

BULLARD, R. D. Unequal protection: environmental justice and communities of color. San Francisco: Sierra Club Books, 1994.

BULLARD, R. D., WRIGHT, B. H. The quest for environmental equity: mobilizing the african-american community for social change. In: DUNLAP, R. E.; MERTIG, A. G. (ed.). American environmentalism: the U.S. environmental movement, 1970-1990. New York: Taylor and Francis, 1992. p. 39-49.

CAMPOS, V. F. TQC: controle da qualidade total, no estilo japonês. Minas Gerais: Nova Lima, 2005.

CAMPOS-VARGAS, Milagros; APARICIO, Alejandra Toscana; ALANÍS, Juan Campos. Riesgos socionaturales: vulnerabilidad socioeconómica, justicia ambiental y justicia espacial. Cuadernos de Geografía, [S.1.], v. 24, n. 2, p. 53-69, 2015. Disponível em: http://www.scielo.org. co/pdf/rcdg/v24n2/v24n2a4.pdf. Acesso em: 10 jun. 2019 .

CASTILHO, Ricardo. Estado: elementos constitutivos, conceito, objetivos e tipos. In: RAMOS, Dircêo Torrecillas. O federalista atual: teoria do federalismo. Belo Horizonte: Arraes, 2013. p. 2-34.

CERRI, Leandro Eugenio Silva. Riscos geológicos associados a escorregamentos: uma proposta para a prevenção de acidentes.
Tese (Doutorado) - UNESP, Rio Claro-SP, 1993.

CICLONE Fani deixa 42 mortos na índia e em Bangladesh. Correios Brasiliense, Brasília, 5 maio 2019c. Disponível em: https://www.correiobraziliense.com. br/app/noticia/mundo/2019/05/05/interna_mundo,753213/ciclone-fani-deixa-42-mortos-na-india-eem-bangladesh.shtml. Acesso em: 10 jul. 2019.

CICLONE Kenneth atinge Moçambique um mês após Idai, que deixou mil mortos: Ciclone resultará, nos próximos dez dias, o dobro de chuvas das que foram originadas pelo ciclone Idai. Exame, São Paulo, 26 abr. 2019a. Disponível em: https://exame.abril.com.br/ mundo/ciclone-kenneth-atinge-mocambique-um-mesapos-idai-que-deixou-mil-mortos/. Acesso em: $30 \mathrm{abr}$. 2019.

CICLONE Kenneth provoca enchentes e deixa mortos em Moçambique: Com 200 mil habitantes, a cidade de Pemba foi atingida pelas fortes chuvas e ao menos 38 pessoas morreram. Exame, São Paulo, 29 abr. 2019b. Disponível em: https://exame.abril.com.br/mundo/ ciclone-kenneth-provoca-enchentes-e-deixa-mortosem-mocambique/. Acesso em: 29 abr. 2019

CLAY E. J. Disasters, vulnerability and the global economy. In: KREIMER, A.; ARNOLD, M. (ed.). The future disaster risk: building safer cities. Washington, D.C. 2003. (Disaster Risk Management Series n.3). p. 3-32

COSTA, Beatriz Souza; OLIVEIRA, Edson Rodrigues de. O patamar hierárquico da Resolução Conama: uma análise pelos óculos da Ação Direta de Inconstitucionalidade 3.074 e holofotes da soberania repúblicana e autonomia dos entes federativos. Revista Argumentum, (RA), Marília, v. 16, p. 209-232, 2015. Disponível em: http://ojs.unimar.br/index.php/revistaargumentum/ article/view/155. Acesso em: 20 mar. 2016.

COUTINHO, Fagner Melo José; AQUINO, Joás Tomaz de. Os $5 \mathrm{~S}$ como diferencial competitivo para o sistema de gestão da qualidade: estudo de caso de uma empresa de aços longos. Revista Gestão.Org, [S. 1.] v. 13, n. 2, p. 176-186, 2015. Disponível em: http://www. revista.ufpe.br/gestaoorg/index.php/gestao/article/ view/738/0. Acesso em: 20 mar. 2019.

CUSTÓDIO, Maraluce Maria; OLIVEIRA, Edson Rodrigues de. A legislação brasileira de uso e ocupação do solo e sua dissonância sistêmica com fatores redutores da refletância da energia solar. Revista de Direito da Cidade, Rio de Janeiro, v. 9, n. 3, p. 867-892, 2017. Di- 
sponível em: https://www.e-publicacoes.uerj.br/index. $\mathrm{php} / \mathrm{rdc} /$ article/view/27045/21067. Acesso em: 5 ago. 2019.

DÁGIOS, Giovanna. Relembre 13 desastres naturais ocorridos no século 21. UOL, São Paulo, 1 nov. 2017. Disponível em: https://www.bol.uol.com.br/unibol/ espm/relembre-13-desastres-naturais-ocorridos-noseculo-21.htm. Acesso em: 29 abr. 2019.

DELECRODE, Carla. Rompimento de barragem é problema recorrente nos Estados brasileiros: nos últimos quatro anos, cerca de oito represas racharam causando grandes prejuízos. Opinião \& Notícia, Rio de Janeiro, 23 jun. 2010. Disponível em: http://opiniaoenoticia.com.br/sem-categoria/rompimento-de-barragem-e-problema-recorrente-nos-estados-brasileiros/. Acesso em: 12 jul. 2019.

DI PIETRO, Maria Sylvia Zanella. Direito administrativo. 27. ed. São Paulo: Atlas, 2014.

DWORKIN, Ronald. O império do direito. Tradução de Jefferson Luiz Camargo. 2. ed. São Paulo: Martins Fintes, 2007

EIRAS, Cahio Guimarães Seabra. Mapeamento de suscetibilidade a eventos perigosos de natureza geológica e bidrológica em São Carlos - SP. 2017. Dissertação (Mestrado) - Escola de Engenharia de São Carlos, da Universidade de São Paulo, São Carlos, 2017. Disponível em: http:/ / www.teses.usp.br/teses/disponiveis/18/18132/tde-01032018095311/en.php. Acesso em: 29 jun. 2019.

FISCHHOFF, Baruch P; KADVANY, John A. Riesgo: una breve introducción. Madrid: Alianza, 2013.

FRASSON, Ieda. Critérios de eficiência, eficácia e efetividade adotados pelos avaliadores de instituicões não-governamentais financiadoras de projetos sociais. 2001. Dissertação (Mestrado em Engenharia de Produção) - Universidade Federal de Santa Catarina, Florianópolis, 2001. Disponivel em: https:/ / repositorio. ufsc.br/bitstream/handle/123456789/82184/175094. pdf?sequence=1. Acesso em: 20 jun. 2019.

FURTADO, André Filipe Pimentel. Avaliação da instabilidade de vertentes e processos de erosão superficial na zona de Castelo Branco, Furnas, ilha de São Miguel, Açores. 2014. Dissertação (Mestrado em Engenharia Geológica) Faculdade de Ciências e Tecnologia, da Universidade Nova de Lisboa, 2014. Disponível em: https://run. unl.pt/bitstream/10362/13955/1/Furtado_2014.pdf. Acesso em: 20 ago. 2019.
GODOY, A. S. Estudo de caso qualitativo. In: GODOI, C. K.; BANDEIRA-DE-MELLO, R.; SILVA, A. B. (org.) Pesquisa qualitativa em estudos organizacionais, paradigmas, estratégias e métodos. São Paulo: Saraiva, 2006.

GOERL, Roberto Fabris; KOBIYAMA, Masato. Redução dos desastres naturais: desafio dos geógrafos. Ambiência, Guarapuava (PR), v. 9, n. 1, p. 145 - 172 jan./ abr. 2013. Disponível em: https://revistas.unicentro. br/index.php/ambiencia/article/view/1935/1934. Acesso em: 20 jun. 2019.

HÁ 3 anos, rompimento de barragem de Mariana causou maior desastre ambiental do país e matou 19 pessoas. Globo, São Paulo, 25 jan. 2019. Disponível em: https:// g1.globo.com/mg/minas-gerais/noticia/2019/01/25/ ha-3-anos-rompimento-de-barragem-de-mariana-causou-maior-desastre-ambiental-do-pais-e-matou-19-pessoas.ghtml. Acesso em: 20 ago. 2019.

HERBERT, D.T.; MATTHEWS, J. A. Geography: roots and continuities. In: MATTHEWS, J. A.; HERBERT, D. T. (org.). Unifying geography: common heritage, shared future. London: Routledge, 2004. p.3-20.

INUNDAÇÕES deixam mais de 30 mortos na Indonésia: na província de Bengkulu, 29 pessoas morreram e 13 estavam desparecidas após as fortes chuvas. Exame, São Paulo, 29 abr. 2019. Disponível em: https:/ / exame.abril.com.br/mundo/inundacoes-deixam-maisde-30-mortos-na-indonesia/. Acesso em: 30 abr. 2019.

INUNDAÇÕES e deslizamentos deixam 51 mortos na África do Sul: serviços meteorológicos advertiram que esta situação se manterá até quarta-feira, podendo afetar pontes e estradas das zonas. Exame, São Paulo, 24 abr. 2019.Disponível em: https:// exame.abril.com.br/mundo/inundacoes-e-deslizamentos-deixam-51-mortos-naafrica-do-sul/. Acesso em: 30 abr. 2019.

JABBUR, Marlon; SABOYA, Felipe. Seminário: compliance e combate à corrupção: políticas de prevenção a desastres ambientais. FGV, Belo Horizonte, 23 - 24 maio 2019. Disponível em: https://direitorio.fgv.br/ eventos/compliance-e-combate-a-corrupcao-politicasde-prevencao-a-desastres-ambientais. Acesso em 25 jun. 2019.

JUSTO FILHO, João Francisco; PIQUEIRA, José Roberto Castilho. Engenharia das catástrofes: entre o determinístico e o imponderável. Estudos avançados, São Paulo, v. 27, n. 77, 2013. Disponível em: http://www.scielo.br/ pdf/ea/v27n77/v27n77a13.pdf. Acesso em: 25 jun. 2019. 
KERVERN, G. Y. Eléments fondamentaux des Cindyniques. Economica, 1995.

KERVERN, G. Y.; RUBISE, P. L'archipel du danger. Economica, 1991.

KOBIYAMA, Masato; PAIXÃO, Maurício Andrades; ZAMBRANO, Fernando Campo; MAZZALI, Laís Helena. MICHEL, Rossano Dalla Lana; GODOY, João Vicente Zancan. Mapeamento de Áreas de Risco para Prevenção de Desastres Hidrológicos com Ênfase em Modelagem Hidrogeomorfológica. 4. ed. Porto Alegre: UFRGS, 6 nov. 2017. Disponível em: https://www.ufrgs.br/gpden/ wordpress/wp-content/uploads/2014/10/ApostilaMapa-4-edi\%C3\%A7\%C3\%A3o-2017_.pdf. Acesso em: 20 jun. 2019.

KUEHN, Roberth R. A taxonomy of environmental justice. Environmental Law Reporter, [S. 1.], v. 30, p. 10681 10703, 2000. Disponível em: https://ir.lib.uwo.ca/cgi/ viewcontent. cgi? article $=1137 \&$ context $=$ aprci. Acesso em: 20 jun. 2019.

LAMA da Samarco pode ser "bomba-relógio" de metais pesados no Rio Doce: rejeitos provenientes do desastre em Mariana (MG) continuam chegando ao estuário do Rio Doce. Jornal da USP, São Paulo, 19 jul. 2018. Disponível em: https://jornal.usp.br/ciencias/ciencias-ambientais/lama-da-samarco-pode-ser-bomba-relogio-demetais-pesados-no-rio-doce/. Acesso em: 20 ago. 2019.

LAVELL, Allan. La gestión local del riesgo: nociones y precisiones en torno al concepto y la práctica. Guatemala: Centro de Coordinación para la Prevención de los Desastres Naturales en América Central (CEPREDENAC), 2003.

LIMA, Verônica Ferreira; MERÇON, Fábio. Metais pesados no ensino de química. UFJF, Juiz de Fora, 27 set. 2011. Disponível em: http://www.ufjf.br/baccan/ files/2012/11/199-CCD-7510.pdf. Acesso em: 3 fev. 2019.

LOCKE, John. Dos tratados sobre o governo. São Paulo: Martins Fontes, 1998.

LOURENÇO, Luciano Fernandes. Riscos e catástrofes programa, conteídos e métodos de ensino2007. Disponível em: https://www.uc.pt/fluc/nicif/. Universidade de Coimbra, Publicacoes/Estudos_de_Colaboradores/PDF/ Relatorios/2007_Riscos_e_cata_strofes.pdf. Acesso e em: 29 jun. 2019.
MARCELINO, E. V., NUNES, L. H., KOBIYAMA, M. Mapeamento de risco de desastres naturais do estado de Santa Catarina. Caminhos da Geografia (UFU), Uberlândia, v. 7, n. 17, p. 72-84, 2006. Disponível em: http://www.seer. ufu.br/index.php/caminhosdegeografia/article/download/15273/8574. Acesso em: 22 ago. 2019.

MARTINES, Fernando. Indenização moral: Estado é isento de culpa, mas empresa é condenada por incêndio na boate Kiss. Consultor Jurídico, São Paulo, 10 set. 2015. Disponível em: http://www.conjur.com.br/2015set-10/estado-isento-empresa-condenadaincendio-boate-kiss. Acesso em: 29 jul. 2019.

MARTÍNEZ, Teresa. 2009. Los geógrafos y la teoría de riesgos y desastres ambientales. Perspectiva Geográfica; [S.l.], v. 14, n. 1, p. 241-263. Disponível em: https:// dialnet.unirioja.es $/$ servlet $/$ articulo? codigo $=3644793$. Acesso em: 10 jun. 2019.

MARTÍNEZ-ALIER, Joan. El ecologismo de los pobres: conflictos ambientales y lenguajes de valoración. 5. ed. Barcelona: Icaria, 2011.

MARTINEZ-ALIER, Joan; TEMPER, Leah; BENE, Daniela Del; Arnim Scheidel. Is there a global environmental justice movement?. The Journal of Peasant Studies, [S. l.] v. 43, n. 3, p. 731-755, 2016. Disponível em: https://www.researchgate.net/publication/301694370_Is_there_a_global_environmental_justice_movement/download. Acesso em: 21 jun. 2019.

MINAS GERAIS. [Constituição (1989)]. Constituição do Estado de Minas Gerais, de 21 de setembro de 1989. Minas Gerais: Diário do Legislativo, Belo Horizonte, 22 set. 1989. Disponível em: https://www.almg.gov.br/ consulte/legislacao/completa/completa-nova-min.htm l? tipo $=$ CON\&num $=1989 \& \mathrm{comp}=\& a n o=1989 \&$ texto =consolidado\#texto. Acesso em: 27 jun.2019.

MINAS GERAIS. Corpo de Bombeiros Militar de Minas Gerais (CBMMG). Ofício CBMMG/CG no. 33/2019: solicitação de informações sobre tramitação da contribuição científica-jurídica do autor Edson Rodrigues de Oliveira. Belo Horizonte, 13 fev. 2019.

MOMENTO exato do rompimento da barragem em Brumadinho (Imagens: TV Globo). Globo, 1 fev. 2019. Disponível em: https://www.youtube.com/ watch?v=9dvTZPwgYVQ. Acesso em: 20 ago. 2019.

MORAES, Alexandre. Direito constitucional. 30. ed. São Paulo: Atlas, 2014. 
MUCKE, Peter. Assessing risk, reducing vulnerability. In: WorldRiskReport 2013. Lars Jeschonnek e MediaCompany, Bonn, 2013. p. 5-10. Disponível em: https:// collections.unu.edu/eserv/UNU:2018/WorldRiskReport_2013_online_01.pdf. Acesso em: 10 jul. 2019.

MUCKE, Peter; SCHMITZ, Peter. What's missing: political determination and consistent implementation. In: WORLDRISKREPORT 2013. Lars Jeschonnek e MediaCompany, Bonn, 2013. p. 57-68. Disponível em: https:// collections.unu.edu/eserv/UNU:2018/WorldRiskReport_2013_online_01.pdf. Acesso em: 10 jul. 2019.

MUNIZ, Daphne Heloisa de Freitas; OLIVEIRA-FILHO, Eduardo Cyrino. Metais pesados provenientes de rejeitos de mineração e seus efeitos sobre a saúde e o meio ambiente. Universitas: Ciências da Saúde, v. 4, n. 1 / 2, p. 83-100, 2006 [ISSN: 1678-5398 83]. Disponível em: https://www.publicacoesacademicas.uniceub.br/ cienciasaude/article/viewFile/24/40. Acesso em 3 fev. 2019

OCCUPATIONAL HEALTH ANS SAFETY ASSESSMENTS SERIES. OHSAS180012007. Sistema de gestão de segurança e saúde ocupacional [Trad. LS2007R1]. British Standards Institution, 2007. Disponível em: https:// comum.rcaap.pt/bitstream/10400.26/7319/2/ Anexo\%20I\%20OHSAS180012007_pt.pdf. Acesso em: 30 jun. 2019.

OLIVEIRA, Edson Rodrigues. A competência constitucional do Corpo de Bombeiros Militar para atuação na proteção ambiental. 2017. Dissertação (Mestrado em Direito) Escola Superior Dom Helder Câmara, Belo Horizonte, 2017. Disponível em: http://www.domhelder.edu.br/ mestrado/editor/assets/arquivos_dissertacoesdefendi das/890a58fa5dbb6d35e38619b40dd232c8.pdf. Acesso em: 4 maio 2019.

OLIVEIRA, Márcio Luís de. A Constituição juridicamente adequada: Transformações do Constitucionalismo e Atualização Principiológica dos Direitos, Garantias e Deveres Fundamentais. Belo Horizonte: Arraes, 2013.

OLIVEIRA, Tales Moreira de. Caracterização de misturas de rejeitos de minério de ferro melhoras com adição de cimento com vistas à aplicação em estradas e aterros. 2013. Dissertação (Mestrado em Engenharia Civil) - Universidade Federal de Viçosa, 2013. Disponível em: https://www.locus. ufv.br/bitstream/handle/123456789/3807/texto\%20 completo.pdf? sequence $=1$ \&isAllowed $=$ y. Acesso em: 20 ago. 2019.
ONDA de calor pode elevar temperatura a $48^{\circ} \mathrm{C}$ na Europa e quebrar recorde. BBC, São Paulo, 2 ago. 2019. Disponível em: https://www.bbc.com/portuguese/internacional-45053346. Acesso em: 3 ago. 2019.

PARREIRAS, Mateus. Bombeiro que considerou barragem da CSN propensa a rompimento é transferido. Documento interno havia definido que o capitão Ronaldo Rosa Lima seria transferido para Barbacena mas, após manifestações, os bombeiros esperaram 56 dias e o enviaram a Poços de Caldas. Jornal Estado de Minas, Belo Horizonte, 5 jan. 2018. Disponível em: https:// www.em.com.br/app/noticia/gerais/2018/01/05/ interna_gerais,928994/bombeiro-que-considerou-barragem-da-csn-propensa-a-rompimento-e-transf.shtm . Acesso em: 28 jun. 2019.

PASSARINHO, Nathalia. Tragédia com barragem da Vale em Brumadinho pode ser a pior no mundo em 3 décadas. BBC News, Londres, 29 jan. 2019. Disponível em: https://www.bbc.com/portuguese/brasil-47034499. Acesso em: 25 jun. 2019.

PESOS específicos de materiais: materiais soltos. Prodetec, São Paulo, 2019. Disponível em: http://www.prodetec.com.br/downloads/pesos_especificos.pdf. Acesso em: 3 fev. 2019.

PETERS, Brainard Guy. O que é governança? Revista do TCU, Brasília, n. 127, maio/ago. 2013. Disponível em: https://revista.tcu.gov.br/ojs/index.php/RTCU/ article/view/87/85. Acesso em: 20 jun. 2019.

PEZZULLO, Phaedra C.; SANDLER, Ronald. Introduction: revisiting the environmental justice challenge to Environmentalism. In: PEZZULLO, Phaedra C.; SANDLER, Ronald (ed.). Environmental Justice and Environmentalism The Social Justice Challenge to the Environmental Movement. Cambridge: MIT, 2007. p. 1-24. Disponível em: http://comphacker.org/comp/engl338/ files /2012/08/Environmental-Justice-and-Environmentalism-The-Social-Justice-Challenge-to-the-Environmental-Movement-Ronald-Sandler-and-PhaedraC.-Pezzullo.pdf. Acesso em: 20 jun. 2019.

PIMENTA, Marcelo Vicente de Alkimim. Teoria da constituição. Belo Horizonte: Del Rey, 2007.

PISKE, Oriana. Mariana: de quem é a responsabilidade pelo maior desastre ambiental brasileiro? Imprensa do TJDFT, Brasília, 22 fev. 2016. Disponível em: http:/ / bdjur.tjdft.jus.br/xmlui/bitstream/handle/ tjdft/32014/MARIANA \%20\%20De\%20quem $\% 20$ 
$\%$ E9 $\% 20$ a $\% 20$ responsabilidade $\% 20$ pelo $\% 20$ maior $\% 20$ desastre $\% 20 \mathrm{am}$ biental $\% 20$ brasileiro. pdf?sequence=1. Acesso em: 20 jun. 2016.

RAWLS, J. A theory of justice. Cambridge, Mass.: Harvard University Press, 1971.

RETROSPECTIVA 2018: catástrofes: principais catástrofes naturais no mundo em 2018. Agência EFE, Madrid [Espanha], 20 dez. 2018. Disponível em: https:/ / www.efe.com/efe/brasil/varios/principais-catastrofes-naturais-no-mundo-em-2018/50000250-3848041. Acesso em: 29 abr. 2019

ROBERTS, J. Timmons. Globalizing environmental justice. In: PEZZULLO, Phaedra C.; SANDLER, Ronald (ed.). Environmental justice and environmentalism the social justice challenge to the environmental movement. Cambridge: MIT, 2007. p. 285-308. Disponível em: http:/ / comphacker.org/comp/engl338/files/2012/08/Environmental-Justice-and-Environmentalism-The-SocialJustice-Challenge-to-the-Environmental-MovementRonald-Sandler-and-Phaedra-C.-Pezzullo.pdf. Acesso em: 20 jun. 2019.

ROCHA, Cármen Lúcia Antunes. República e federação no Brasil: traços constitucionais da organização política brasileira. Belo Horizonte: Del Rey, 1997.

ROSSI, Marina. Tragédia em Brumadinho: quantos erros ainda serão necessários até que a Vale aprenda? [Dez dias após o rompimento da barragem, Fiocruz alerta para doenças que podem acometer a cidade e fazer perdurar essa tragédia por meses, a exemplo de Mariana. El País, São Paulo, 5 fev. 2019. Disponível em: https://brasil.elpais.com/brasil/2019/02/05/politica/1549395601_506614.html. Acesso em: 5 fev. 2019.

ROUSSEAU, Jean-Jacques. Carta de Rousseau a Voltaire sobre a providência. Tradução e aparato crítico de Maria das Graças de Souza. In: MENEZES, Edmilson (org.). História e providência: Bossuet, Vico e Rousseau. Ilhéus: Editus, 2006.

RUTHERFORD, W.H.; BOER, J. The definition and classification of disasters. Injury, [S.1.], v. 15, p. 10-12, 1983.

SABOYA, Érica; BETIM, Felipe. Temporal no Rio deixa mortos, soterra ônibus e destrói, novamente, ciclovia: ventos atingiram $110 \mathrm{~km} / \mathrm{h}$ e sirenes que alertavam moradores para deixar suas casas soaram na Rocinha. Ao menos seis pessoas morreram. El País, São Paulo,
7 fev. 2019. Disponível em: https://brasil.elpais.com/ brasil/2019/02/07/politica/1549542559_653158. html. Acesso em: 30 fev. 2019.

SANDLER, Ronald (ed.). Environmental justice and environmentalism the social justice challenge to the environmental movement. Cambridge: MIT, 2007. p. 285-308. Disponível em: http://comphacker.org/comp/engl338/ files /2012/08/Environmental-Justice-and-Environmentalism-The-Social-Justice-Challenge-to-the-Environmental-Movement-Ronald-Sandler-and-PhaedraC.-Pezzullo.pdf. Acesso em: 21 jun. 2019.

SCHLOSBERG, David. Reconceiving environmental justice: global movements and political theories. Environmental politics, [S.l.], v. 13, n. 3, p. 517540, 2004. Disponível em: https://www.uea.ac.uk/ documents /40159/0/hh6-schlosberg-reconceiving-ej2004/6bf17634-9470-4321-82db-7c6c1c5274b8. Acesso em: 21 jun. 2019.

SCHUBERT, Kirsten; GEBAUER, Thomas. The creeping disaster: global health in crisis. In: WORLDRISKREPORT 2013. Lars Jeschonnek e MediaCompany, Bonn, 2013. p. 34-44. Disponível em: https:/ / collections.unu.edu/eserv/UNU:2018/WorldRiskReport_2013_online_01.pdf. Acesso em: 10 ago. 2019.

SILVA, José Afonso da. Curso de direito constitucional positivo. 37. ed. São Paulo: Malheiros, 2013.

SILVÉRIO, Mariana Strassacapa. Projeto Três Gargantas: cidade e território na China. 2012. Monografia (Graduação e Arquitetura e Urbanismo) - Faculdade de Arquitetura e Urbaanismo da Universidade de São Paulo, São Paulo, 2012. Disponível em: http://www.metropolefluvial.fau.usp.br/downloads/projetos/GMF_ensino-tfg_strassacarpa.pdf. Acesso em: 5 jun. 2019.

SÓLON, Ari Marcelo. Teoria da soberania como problema da norma jurídica e da decisão. Porto Alegre: Fabris, 1997.

SOLUÇÃO de continuidade. In: DICIONÁRIO Priberam da Língua Portuguesa [em linha], 2008-2013, Disponível em: https://dicionario.priberam.org/ solu $\%$ C3\%A 7\%C3\%A3o\%20de $\% 20$ continuidade. Acesso em: 20 jul. 2019.

UNITED NATIONS DEVELOPMENT PROGRAMME. Human development indices and indicators 2018. UNDP, 29 feb. 2019, Disponível em: http://www. br.undp.org/content/brazil/pt/home/library/idh/ relatorios-de-desenvolvimento-humano/relatorio-do- 
desenvolvimento-humano-2018.html. Acesso em: 26 jul. 2019.

VERDEL, Tierry. Méthodologies d'évaluation globale des risques: applications potentielles au génie civil. [S. 1: s. n.], 2005.

VILLENA, Juan José; ROBLES, Tiago. Ciclone Fani: os vídeo mais impactantes: compilação dos vídeos mais virais do Ciclone Tropical Fani: a tempestade já deixa 11 mortos e milhões de evacuados em Orissa e Bangladesh: os danos são incontáveis. O tempo.com, São Paulo, 4 maio 2019. Disponível em: https://www.tempo.com/ noticias / actualidade/ciclone-fani-os-videos-mais-impactantes.html. Acesso em: 4 maio 2019.

WEBER, Marx. Economia e sociedade: fundamentos da sociologia compreensiva. Tradução de Regis Barbosa e Karem Elsabe Barbosa. Brasilia: UNB, 2004. v. 2.

WELLE, Torsten; BIRKMANN, Jörn; RHYNER, Jakob, WITTING, Maximilian, WOLFERTZ, Jan. WorldRiskIndex 2013. In: WORLDRISKREPORT 2013. Lars Jeschonnek e Media Company, Bonn, 2013, p.45-56. Disponível em: https://web.archive.org/ web/20140816173655/http://www.worldriskreport. com/uploads/media/WorldRiskReport_2013_online_01.pdf\#. Acesso em: 20 jun. 2019.
WENZ, Peter. Does environmentalism promote injustice for the poor? In: SANDLER, Ronald; PEZZULLO, Phaedra C. (ed.). Environmental justice and environmentalism the social justice challenge to the environmental movement. Cambridge: MIT, 2007. p. 57-84. Disponível em: http:// comphacker.org/comp/engl338/files/2012/08/Environmental-Justice-and-Environmentalism-The-SocialJustice-Challenge-to-the-Environmental-MovementRonald-Sandler-and-Phaedra-C.-Pezzullo.pdf. Acesso em: 20 jun. 2019.

YIN, R. K. Estudo de caso: planejamento e métodos. Porto Alegre: Bookman, 2015. 
Para publicar na Revista de Direito Internacional, acesse o endereço eletrônico www.rdi.uniceub.br ou www.brazilianjournal.org.

Observe as normas de publicação, para facilitar e agilizar o trabalho de edição. 